\title{
The role of zooplankton in the pelagic-benthic coupling of the Southern Ocean*
}

\author{
SIGRID B. SCHNACK-SCHIEL ${ }^{1}$ and ENRIQUE ISLA ${ }^{2}$ \\ ${ }^{1}$ Alfred-Wegener-Institut für Polar- und Meeresforschung, 27515 Bremerhaven, Germany. \\ E-mail: sschiel@awi-bremerhaven.de \\ ${ }_{2}^{2}$ Institut de Ciéncies del Mar, 08015 Barcelona, Spain.
}

\begin{abstract}
SUMMARY: Zooplankton contributes in different ways to pelagic-benthic coupling: Their faecal material is a major route of energy flow and the vertical migrations of many species as well as the production of pelagic larvae by benthic organisms represent different paths to link the two subsystems. Antarctic particle fluxes have been shown to be highly variable in size and composition within a given region and even at the same site from year to year. There are also differences throughout the water column, where particle fluxes close to the sea floor beyond the continental shelf break do not normally show seasonal variation within shallow environments. Commonly, at depths shallower than $500 \mathrm{~m}$, the most evident feature is that more than $90 \%$ of the annual fluxes occur during a short period of the spring-summer. This event is masked near the seabed at greater depths due to resupension and lateral advection of particles. Faecal material of various origins is one of the main constituents of the biogenic matter flux. It usually reaches its maximum in February once the early phytoplankton bloom has developed. However, the presence of faecal pellets is ubiquitous during the months of the year when there is enough light to support primary production. At this stage more research is needed to elucidate the particular role of distinct taxaincluding among others salps, krill, copepods and protozoans - in the transport of organic matter to the benthos, and their contribution to the biogeochemical cycles of carbon, nitrogen, phosphorus and silicon. Aggregation of particles is another important process controlling the development and dynamics of pelagic-benthic coupling due to its influence on the sinking velocity of particles and the enhancement of organic matter utilisation by members of the microbial loop in the upper layers of the water column. Also in shallow waters, aggregation favours the transfer of high-quality organic matter to the benthic realm. At greater depths resuspended aggregates and single particles from shallow environments may constitute a considerable fraction of the "fresh" biogenic flux. Submarine canyons accelerate and cause more efficient transfer of energy to the deep-sea benthos. Both faecal pellets and aggregation increase the original sinking velocity of individual particles and reduce their residence time in the water column, thus creating rich organic mats over the seabed in shallow environments. In the Southern Ocean these rapid organic matter transfers are important since they allow the accumulation of highly nutritive material, which may fuel the benthos during the dark months due to constant resuspension by tidal currents. Several factors control the particle fluxes in the Southern Ocean, such as size and composition of phytoplankton blooms, currents, seasonality, depth, and ice coverage. Due to this complexity, despite many efforts there is still a long way to go before the pathway of this ecologically important link can be fully understood and described. Our knowledge of the pelagic-benthic coupling in the Magellan region is still extremely limited and offers many opportunities for future scientific research. The same holds true for the production of meroplanktonic larvae in the Southern Ocean.
\end{abstract}

Keywords: particle flux, faecal pellets, vertical migration, meroplankton, pelagic-benthic coupling.

RESUMEN: El zooplancton contribuye de diferentes maneras al acoplamiento pelago-béntico: El hundimiento de su material fecal representa un flujo de energía muy importante y las migraciones verticales de muchas especies así como la producción de larvas pelágicas por organismos bénticos son dos ejemplos de conexión entre ambos subsistemas. En la Antártida, se ha detectado que los flujos de partículas varían en magnitud y composición dentro de una región e incluso en el mismo sitio entre año y año. También hay diferencias a lo largo de la columna de agua siendo que, generalmente, los flujos cerca del fondo marino más allá de la plataforma continental no presentan la variación temporal medida en ambientes más someros. Comúnmente, a profundidades menores a $500 \mathrm{~m}$, la característica más evidente es que más del $90 \%$ del total del flujo anual de par- 
tículas ocurre durante un período corto de la temporada primavera-verano. Cerca del lecho marino este evento queda enmascarado debido a la resuspensión y el aporte lateral. El material fecal es uno de los constituyentes principales del flujo de material biogénico. Generalmente alcanza el valor máximo en Febrero, cuando el florecimiento temprano de fitoplancton se ha desarrollado. Sin embargo, los paquetes fecales son omnipresentes durante los meses del año en que hay luz suficiente para mantener la producción primaria. En este punto, se necesita intensificar la investigación para identificar la importancia de cada grupo taxonómico, por ejemplo, salpas, krill, copépodos y protozoarios, en el transporte de material orgánico al bentos y su participación en los ciclos biogeoquímicos del carbono, nitrógeno, fósforo y sílice. La adsorción de partículas es otro mecanismo importante en el control del desarrollo y la dinámica del acoplamiento pelago-béntico debido a la influencia que ejerce sobre la velocidad de hundimiento de las partículas y la utilización de la materia orgánica por los miembros de la comunidad microbiana en las capas superiores de la columna de agua. La adsorción de partículas en aguas someras también favorece la transferencia de material orgánico con buena calidad nutritiva al ambiente béntico. Paralelamente, los cañones submarinos aceleran y hacen más eficiente el transporte de energía al bentos del mar profundo. A mayor profundidad, la resuspensión de agregados y partículas individuales provenientes de ambientes someros puede constituir una fracción considerable del flujo de material biogénico "fresco". Los paquetes fecales y la adsorción de partículas aumentan la velocidad original de hundimiento de partículas individuales y reducen su tiempo de residencia en la columna de agua, creando en ambientes someros alfombras ricas en material orgánico sobre el lecho marino. En el Océano Austral la transferencia rápida de material orgánico al fondo del mar es especialmente importante ya que permite la acumulación de material orgánico con alto contenido nutritivo que servirá para alimentar al bentos durante los meses de oscuridad gracias a la resuspensión constante por corrientes de marea. Varios factores controlan el flujo de partículas en el Océano Austral, por ejemplo, el tamaño y la composición de las proliferaciones de fitoplancton, las corrientes, la variación estacional y la profundidad y la extensión del área cubierta por hielo. Esta complejidad hace que, a pesar de muchos esfuerzos, aún quede mucho por estudiar para conocer completamente las rutas de este importante vínculo ecológico. Nuestro conocimiento del acoplamiento pelago-béntico en la región del Estrecho de Magallanes es aún extremadamente limitado por lo que este tema ofrece productivas oportunidades de investigación, lo mismo es válido para la producción de larvas meroplanctónicas en el Océano Austral.

Palabras clave: flujos de partículas, paquetes fecales, migración vertical, meroplancton, acoplamiento pelago-béntico.

\section{INTRODUCTION}

The knowledge of the vertical flux of particulate material from the euphotic zone and its chemical and taxonomic composition is essential for the understanding of marine biogeochemical cycles. This pelagic-benthic coupling is a major route for energy flow. Zooplankton play a major role within the pelagic-benthic coupling, contributing in various ways to the energy flow, as their nitrogenous excretion is a major source of nutrients for algal growth and their faecal material, carcasses and exuvia sink and settle onto the seabed. Many holoplankton organisms perform diel and ontogenetic migrations covering the whole water column, connecting sea surface and sea bottom. Due to a downward migration, these species may come close to the sediment and provide a food source for benthic invertebrates. Benthic organisms often reproduce via planktonic larvae (meroplankton), which may seasonally contribute in high abundances to the zooplankton community.

\section{Particle flux}

Between $<10$ and $70 \%$ of the primary production of the euphotic layer reaches the benthic realm, depending on the region and the time of the year (Hargrave, 1973; Joint and Morris, 1982). A strong correlation between sedimentation of phytoplankton and benthic macro-faunal biomass/production has been observed worldwide (Joint and Morris, 1982;
Billet et al., 1983; Smetacek, 1984; Albertelli et al., 1998; Gili et al., 2001). However, sedimentation of phytoplankton cells is a complex process, and interactions between the pelagic and benthic systems are related to hydrographical and biological controls (Smetacek, 1984). The hydrographical controls are determined by the local wind, current regime, lateral advection and resuspension (Wassmann, 1984; Leventer and Dunbar, 1987; Jaeger et al., 1996; Baldwin et al., 1998; Dunbar et al., 1998; Isla et al., 2001; Povero et al., 2001; Palanques et al., 2002a; Baldwin and Smith, 2003), and in polar seas also by the ice dynamics (Leventer and Dunbar, 1996, Dunbar et al., 1998; Pusceddu et al., 1999; Palanques et al., 2002b). The biological factors influencing sedimentation are the sinking of individual cells (Billet et al., 1983; Wassmann, 1984; Fukuchi et al., 1988; Bathmann et al., 1991), the formation of aggregates and marine snow (Fowler and Knauer, 1986; Riebesell et al., 1991; Karl et al., 1991; Smith et al., 1999; Kiørboe, 2001) and grazing by herbivores such as euphausiids and salps, which result in the transportation of packed phytoplankton cells and organic debris via faecal pellets to deeper water layers (Bishop et al., 1977; Brulander and Silver, 1981; Urrère and Knauer, 1981; Joint and Morris, 1982; Fowler and Knauer, 1986; Emerson and Roff, 1987; Noji et al., 1991; Dagg et al., 2003; Huiskin et al., 2004). Faecal pellet quality varies among zooplankton species and this is reflected in the quality of organics exported from the euphotic layer. For example, the food is thoroughly shredded in 

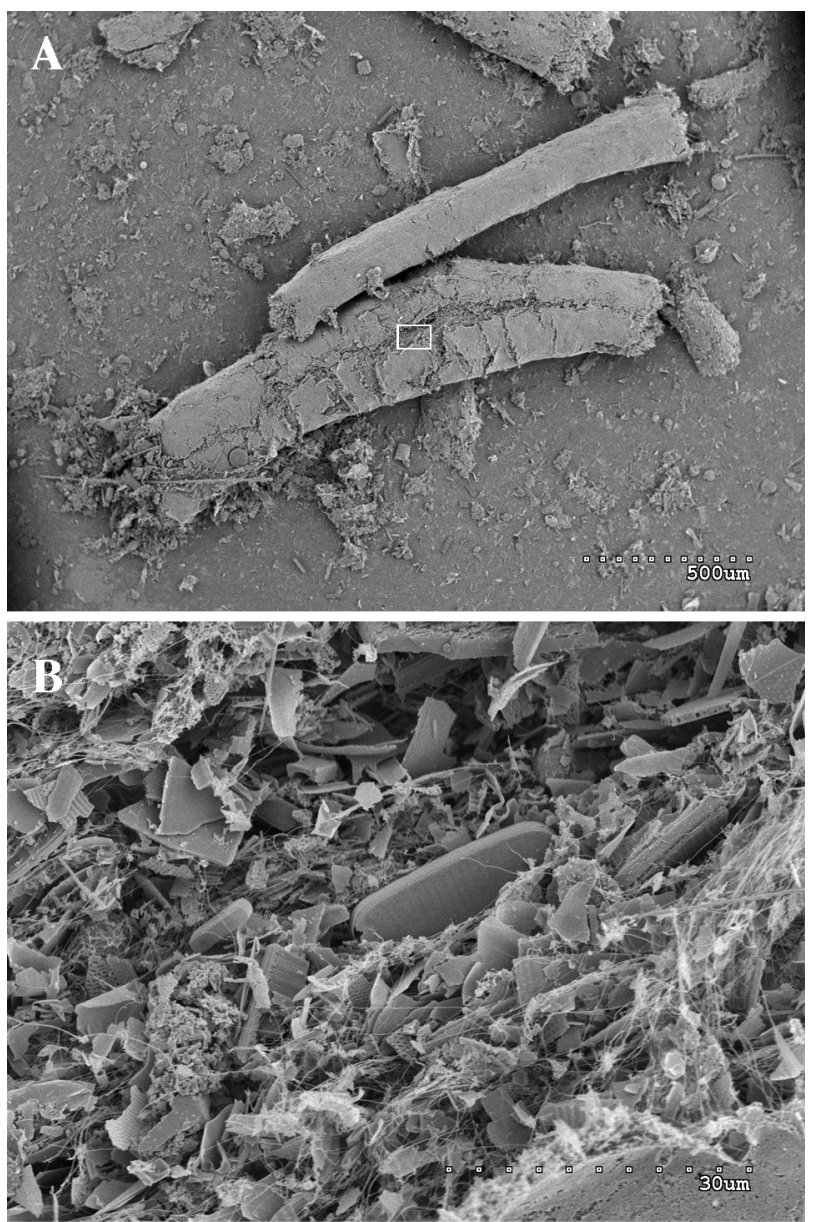

FIG. 1. - Scanning electron microscope images of faecal pellets collected with sediment traps, 30 metres above the bottom at $480 \mathrm{~m}$ depth on the eastern Weddell Sea shelf, showing, A) faecal pellets and B) empty diatom frustules and debris. The white rectangle in A corresponds to the area of image B.

euphausiids, and hence only a few intact phytoplankton cells and frustules occur in their faeces (Fig. 1). In contrast, numerous intact cells and unbroken frustules have been found in the faecal matter of salps (Peinert et al., 1989), which presented C:N ratios close to the values of living phytoplankton (Bruland and Silver, 1981). Hence, salp faeces represent an important source of high quality food for the benthic realm. Faecal matter consists of both organic and inorganic material, which is more or less densely packaged and constitutes between $<1 \%$ and almost $100 \%$ of the material collected with sediment traps (Urrère and Knauer, 1981; Bodungen et al., 1987; Karl et al., 1991; Accornero and Gowing, 2003). A reduced contribution of faecal pellets to settling material has been interpreted as the result of coprophagy, mechanical breakage and microbial attack (Paffenhöfer and Knowles, 1979; Turner and Ferrante, 1979; Hoffmann et al., 1981; Noji et al., 1991; Kiørboe, 2000). The role of attached prokary- otes converting large, rapidly sinking particles, into small, non-sinking particles of 0.3-0.6 $\mu \mathrm{m}$ was proposed by Cho and Azam (1988). It is now well established that zooplankton faecal pellets, especially those with small sizes, are grazed in the water column (Turner and Ferrante, 1979; Paffenhöfer and Knowles, 1979; Bishop et al., 1980, Hoffmann et al., 1981; Emerson and Roff, 1987; González and Smetacek, 1994). The sedimentation rate of the pellets depends on their content, shape, size, and the presence or absence of a peritrophic membrane (Cadée et al., 1992). For example, the smaller the producers, the smaller the amount of pellets reaching the sea floor. Faecal pellets produced by larger zooplankton (such as euphausiids) sink rapidly throughout the water column (Komar et al, 1981; Lorenzen and Welschmeyer, 1983; Fowler and Knauer, 1986), and may exert a positive influence on the magnitude of benthic production. The arrival on the sea floor of faecal pellets with high nutritive value (e.g. rapid sinking pellets of salps) is welcomed by benthic organisms such as hydrozoans, corals and glass sponges, which feed directly on them and benefit from their organic contents (Orejas et al., 2000; Duineveld et al., 2004; Leys et al., 2004).

The magnitude and pattern of biogenic export are considered to be related to the planktonic food web structure in the euphotic layer, i.e. by the size structure of primary production and the match/mismatch between primary production and grazing. Hence, when algal production and herbivorous consumption are in phase, most algal cells are packaged as faecal material before sinking out. On the other hand, when algal production and herbivore consumption are out of phase, a probably large proportion of algae sink directly to the ocean floor (Billet et al., 1983; Legendre and Le Fèvre, 1989; Legendre and Rassoulzdegan 1996). In contrast, Rivkin et al. (1996) concluded from their studies in the Gulf of St. Lawrence that sedimentation processes are independent of the main trophic mode and are not related to the dominance of herbivorous or microbial trophic pathways. Fluxes of chlorophyll and mesozooplankton faecal pellets from the euphotic zone were 1 to 21 times greater and 2 to 6 times smaller during and after the phytoplankton bloom respectively. However, fluxes of POC and PON were similar in the two seasons. Thus, the POC fluxes were similar during the spring phytoplankton bloom, when herbivory dominated, and during postbloom conditions, when microbial and omnivorous food webs prevailed. 
Water depth is another important controlling factor on the quality of biogenic particle fluxes. Vertical fluxes of particles throughout relatively shallow depths are exposed to short residence times in the water column, which results in them arriving at the seafloor in a relatively fresh condition (Isla et al., 2001; Baldwin and Smith, 2003). Furthermore, the upper $100 \mathrm{~m}$ of the water column has been identified as an "aggregation" layer, whereas in the region below decomposition dominates biogenic particle transformation (Boyd et al., 1999). Thus, due to the direct sinking of autotrophs, shallow areas receive rapid sedimentary pulses of high-quality organic matter. This scenario is mainly typical of the spring and summer periods with low standing stocks of zooplankton (Peinert et al., 1989). Fluff layers derived from settled phytoplankton were also observed at deep-sea sites in all oceans where it also appeared to be a seasonal phenomenon (Beaulieu, 2002).

In polar seas the period of high primary productivity in the water column is short, and hence particle flux is characterised by high seasonality which displays an episodic signal including significant metabolic responses in benthic organisms (Matsuda et al., 1990; Fabiano et al., 1997). Much of the sedimented material seems to be utilised immediately by the large stocks of epibenthic suspension feeders (Gili et al., 2001). However, deposits of phytodetritus on the shelves of the Weddell, Lazarev and Bellingshausen Seas indicate heavy sedimentation of phytoplankton largely unutilised by the benthos (Barthel, 1997; Gutt et al., 1998; Isla et al., unpubl.).

\section{Vertical migration}

Many zooplankton species perform daily vertical migrations, but in high latitudes seasonal or ontogenetic migrations are probably more important. Classically, during diel migration patterns the organisms migrate actively upwards from the deeper waters towards the surface layers at night when they feed, and they descend again to their daytime depths at dawn. The seasonal/ontogenetic migration pattern is characterised by the occurrence of different developmental stages at different depths in different seasons (reviewed by Longhurst, 1976). These vertical migration patterns are another example of pelagicbenthic coupling resulting in a downward transfer of organic material. On the one hand, faecal pellets are produced by migrants at depth from material gathered near the surface; on the other hand, the migrants become potential food for deeper living and benthic predators (Angel, 1989).

\section{Meroplanktonic larvae}

Pelagic-benthic coupling also occurs in the opposite direction, from the benthos to the pelagial via meroplanktonic larvae of benthic animals. Meroplanktonic larvae occur in many neritic parts of the oceans, at high latitudes. However, a general trend towards non-pelagic development and the predominance of brooding benthic species due to the unsecurity of prolonged larval life in the pelagial, where primary production is restricted to a short period each year, was assumed by Thorson (1950). This is known as "Thorson`s rule". The relative absence of pelagic larvae has been discussed extensively, and recently an increased number of benthic species with pelagic larvae have been identified. Some of these even have planktotrophic larvae, which raises doubts on the general validity of this rule. However, meroplanktonic larvae are still not as common in the Antarctic as would be expected from the high number of benthic species (reviewed by Arntz et al., 1994; Arntz and Gili, 2001). In contrast to the Southern Ocean, high abundances of invertebrate larvae occur in the Magellan region (Antezana, 1999; Defren-Jason et al., 1999; Thatje et al., 2003).

\section{PELAGIC-BENTHIC COUPLING IN THE ANTARCTIC PARTICLE FLUX}

\section{Modes of particle transportation}

Phytoplankton material leaves the surface layers primarily as large aggregates or via sinking faecal pellets (Bodungen et al., 1987; 1988; Wefer et al., 1988; Leventer, 1991; Dunbar et al., 1998, Smith and Dunbar, 1998; Frignani et al., 2000; Anadón et al., 2002; Accornero and Gowing, 2003). The exceptions include mass fallout of diatom cells (particularly Thalassiosira antarctica) from blooms in shallow coastal water (Bodungen et al., 1986; Matsuda et al., 1987; Fukuchi et al., 1988; Handa et al., 1992).

In the Southern Ocean, spring particulate matter that is transported from the surface into deeper waters consists mainly of material of phytoplanktonic origin, and high fluxes are commonly linked to the presence of marginal ice or post-bloom conditions (Bodungen et al., 1986; Frignani et al., 2000). During non-bloom conditions, downward fluxes are 
generally low and often made up of amorphous, unidentifiable material (Schnack, 1985; Anadón et al., 2002). During this time of the year, material of zooplankton origin is seldom found in sediment traps, which probably mirrors the low density of zooplankton near the surface. Hence, this phytoplankton pulse occurs before the herbivorous zooplankton massively graze on the algal community, and represents a rapid, highly-rich organic matter transfer to the sea floor. In summer, faecal material of zooplankton seem to be the major vector for vertical transportation of particulate organic matter throughout the water column to the sea floor (Bodungen, 1986; Wefer et al., 1988; Palanques et al., 2002 a; b). Faeces of euphausiids in particular, and probably those of other large zooplankton such as salps, are important in summer, when they reach their highest concentrations. Local mass fluxes of faecal strings from krill have been observed during krill swarms (Bodungen, 1986; Bodungen et al., 1987; Wefer et al., 1988; Cadée, 1992). In the absence of krill swarms, the significance of small faeces increases (Bodungen et al., 1988).

The faecal pellets of the various taxa differ in shape and size and are hence characteristic of each taxon. Different morphology types such as round, spherical, ellipsoidal, oval, cylindrical, triangular and elongated are recorded from trap material in the Southern Ocean. However, the producers of the various pellet types are not always easy to identify. Protozoans such as heterotrophic dinoflagellates and radiolarians are supposed to produce small round, ellipsoidal to spherical pellets (Nöthig and Bodungen, 1989; Buck et al., 1990; González, 1992a;b; Thomas et al., 2001). Ellipsoidal pellets are attributed to copepods (González et al., 1994) and cylindrical pellets (also often called faecal strings) to euphausiids (Bodungen, 1986; Cadée et al., 1992). However, the producers of many pellet types are still uncertain (see Accornero and Gowing, 2003).

The size of the pellets depends on the producer size, and hence pellets range in size from a few micrometres ("minipellets") produced by protozoans (3-50 $\mu \mathrm{m})$ (Gowing and Silver, 1985; Nöthig and Bodungen, 1989; Buck et al., 1990; González, 1992a) to several millimetres in length produced by large zooplankton organisms such as the Antarctic krill, Euphausia superba. Krill produce faeces as large as $660 \mu \mathrm{m}$ in diameter and usually 1 to $5 \mathrm{~mm}$ in length (Marchant and Nash, 1986; González, 1992b).

Faecal pellets are found to be important contributors to the downward particle flux in all studied regions of the Southern Ocean and the highest contributions were observed during most periods of maximum sedimentation (Bodungen et al., 1987; 1988; Fischer et al., 1988; Dunbar et al., 1998). Pellet contributions to carbon flux are reported to range from 4 to 59\% in the Ross Sea (Accornero and Gowing, 2003) and up to $90 \%$ at the marginal ice zone in the Scotia Sea (Cadée et al., 1992) and in the Bransfield Strait (Bodungen, 1986, Bodungen et al., 1987; Wefer et al., 1988). The high contributions in the latter two regions are attributed to the faecal strings of Euphausia superba, which were the most important carrier of particles.

The content of krill faecal strings is finely shredded and rarely contains intact cells (Bodungen, 1986; Gersonde and Wefer, 1987). According to Bodungen et al. (1987) and Wefer et al. (1988), the vertical flux was not related to phytoplankton standing stock and primary production, but to the abundance of krill. Krill swarms consume the majority of the phytoplankton in the upper water layers, and enhance the downward transport of biogenic particles such as diatom frustules also in addition to lithogenic particles in their large fast-sinking faecal strings. Hence, loss of organic matter from the illuminated surface layer is almost entirely mediated by krill. This is in sharp contrast to the Ross Sea, where faecal strings of euphausiids are only rarely found in trapped material (Dunbar et al., 1989; Fabiano et al., 1997; Asper and Smith, 1999; Langone et al., 2000), coincident with the low abundances of krill (Dunbar et al., 1998). High fluxes in the Ross Sea late in the season are carried out by the pteropod Limacina helicina, and the contribution of pteropod shells can reach nearly $50 \%$ of the total flux. The tests of the pteropods were mainly empty and were not considered to be "swimmers", which had actively migrated into the traps but directly settled after death (Dunbar, 1984; Collier et al., 2000). It has been speculated by Gardner et al. (2000) that the reason for the crash could also have been the naked pteropod Clione limacina, which feeds specifically on Limacina helicina.

Similarly, Baldwin and Smith (2003) did not consider the highly abundant copepods during winter/early spring in the sedimented traps in Port Foster/Deception Island as "swimmers" due to the fact that they were partially decomposed. The high amount of copepods in the traps coincided with a change in the pelagic community. King and LaCasella (2003) and Kaufmann et al. (2003) observed an anomalous increase in the calanoid 
TABLE 1. - Selected annual total flux data and occurrence of peak flux.

\begin{tabular}{|c|c|c|c|c|c|}
\hline & $\begin{array}{l}\text { Trap depth } \\
(\mathrm{m})\end{array}$ & $\begin{array}{l}\text { Total flux } \\
\mathrm{g} \mathrm{m}^{-2} \mathrm{yr}^{-1}\end{array}$ & month & $\operatorname{lux}_{\%}$ of total & Reference \\
\hline \multicolumn{6}{|l|}{ Oceanic } \\
\hline Polar Front (Atlantic) & 700 & 38.3 & Jan-Feb & 89 & Wefer and Fischer (1991) \\
\hline \multirow[t]{2}{*}{ Maud Rise (Atlantic) } & 4456 & 7.9 & Feb-May & 59 & Wefer et al. (1990) \\
\hline & 360 & 33.7 & Jan-May & 91 & Wefer and Fischer (1991) \\
\hline Northern Weddell Sea (Atlantic) & 863 & 0.4 & Feb-Mar & 90 & Fischer et al. (1988) \\
\hline Polar Frontal Zone (Pacific) & 982 & 33.5 & Dec-Jan & 64 & Honjo et al. (2000) \\
\hline Antarctic Polar Front (Pacific) & 1003 & 56.9 & Nov-Mar & 93 & Honjo et al. (2000) \\
\hline Antarctic Circumpolar Current (Pacific) & 1031 & 80.6 & Nov-Mar & 90 & Honjo et al. (2000) \\
\hline Ross Gyre, Antarctic Zone (Pacific) & 937 & 27.6 & Jan-Feb & 83 & Honjo et al. (2000) \\
\hline \multicolumn{6}{|l|}{ Neritic } \\
\hline \multirow[t]{4}{*}{ King George I., Bransfield Strait (Atlantic) } & 494 & 120.0 & Jan & 77 & Wefer et al. (1988) \\
\hline & 1588 & 107.7 & Dec-Jan & 97 & Wefer et al. (1988) \\
\hline & 693 & 11.9 & Dec & 96 & Wefer et al. (1990) \\
\hline & 687 & 36.6 & Nov-Dec & 95 & Wefer et al. (1990) \\
\hline \multirow{2}{*}{ Livingston I., Bransfield Strait (Atlantic) } & 500 & 4.1 & Nov-Jan & 99 & Palanques et al. (2002a;b) \\
\hline & 1000 & 1326.0 & Aug-Sep & 25 & Palanques et al. (2002a;b) \\
\hline \multirow{2}{*}{ Joides Basin, Ross Sea (Pacific) } & 211 & 3.9 & Jan & 99 & Langone et al. (2000) \\
\hline & 540 & 30.0 & Dec-Feb & 88 & Langone et al. (2000) \\
\hline Joides Bay, Ross Sea (Pacific) & 200 & 16.7 & Mar-Apr & 51 & Collier et al.(2000) \\
\hline \multirow[t]{3}{*}{ Southcentral Ross Sea (Pacific) } & 206 & 33.2 & Feb-May & 92 & Collier et al.(2000) \\
\hline & 481 & 84.5 & Jan-Jun & 90 & Collier et al.(2000) \\
\hline & 465 & 69.3 & Feb-Jun & 90 & Collier et al.(2000) \\
\hline \multirow[t]{2}{*}{ Southwestern Ross Sea (Pacific) } & 230 & & Feb & 96 & Dunbar et al. (1998) \\
\hline & 719 & & Jan-Mar & 72 & Dunbar et al. (1998) \\
\hline \multirow{2}{*}{ Central Ross Sea (Pacific) } & 230 & & Feb-Mar & 86 & Dunbar et al. (1998) \\
\hline & 519 & & Feb-Mar & 80 & Dunbar et al. (1998) \\
\hline \multirow[t]{2}{*}{ Northwestern Sea (Pacific) } & 230 & & Feb-Mar & 85 & Dunbar et al. (1998) \\
\hline & 493 & & Jan-Mar & 84 & Dunbar et al. (1998) \\
\hline
\end{tabular}

copepod Metridia gerlachei as well as of the predatory ctenophore Callianira spp. Hence, the crash of the copepod population was coincident with the occurrence of the predator. However, metazooplankton remains such as carcasses and moults are only rarely recorded in sediment trap material (Angel, 1984). This is probably due to their rapid degradation (Small and Fowler, 1973) or ingestion before reaching greater depth (Fowler and Knauer, 1986). Yet another reason could be that they are perhaps produced by deep water animals (Wishner, 1980) dwelling just over the traps (Honjo et al., 1982).

The planktic foraminifer Neogloboquadrina pachyderma is also reported from sedimented material in various Southern Ocean regions, including ice-covered areas, and accounts for most of the calcium carbonate flux (Fukuchi and Sasaki, 1981; Wefer et al., 1982; Bodungen et al., 1986; Wefer et al., 1990; Wefer and Fischer, 1991; Collier et al., 2000; Langone et al., 2000).

\section{Annual particle flux}

Long-term time-series sediment trap studies have shown that particle flux is related to biological processes in the surface layer. Total annual flux rates in offshore areas in the Southern Ocean vary greatly between sites (Table 1). The lowest annual particle flux $\left(0.371 \mathrm{~g} \mathrm{~m}^{-2} \mathrm{yr}^{-1}\right)$ yet observed in the world ocean was found by Fischer et al. (1988) in 1985/86 in the north-central Weddell Sea at $863 \mathrm{~m}$ depth. About $80 \%$ of the total flux was biogenic opal, while $17 \%$ was organic matter. Slightly elongated faecal pellets of about $0.5 \mathrm{~mm}$ in diameter and of unknown origin played the most important role in the vertical transport of the material, and about 94,000 pellets $\mathrm{m}^{-2} \mathrm{yr}^{-1}$ were counted (Wefer et al., 1990). Diatom frustules were the major constituent of the pellets. Spring sea-ice thaw events rather than the occurrence of larger open seas seemed to be responsible for the great seasonal variability of particle flux (Fischer et al., 1988). Fluxes as high as 56.9 and $80.6 \mathrm{~g} \mathrm{~m}^{-2} \mathrm{yr}^{-1}$ were observed in the oceanic region of the Antarctic Polar Front and the Antarctic Circumpolar Current respectively (Honjo et al., 2000). The annual total flux in neritic regions of the Antarctic also shows a high variability (Table 1). In the deep but neritic Bransfield Strait, Antarctic Peninsula, sediment traps deployed in mid-water layers between 494 and $687 \mathrm{~m}$ depth south of King George Island recorded total annual values of 120 (1983/1984), 11.9 (1984/1985), and $36.6 \mathrm{~g} \mathrm{~m}^{-2} \mathrm{yr}^{-1}$ 
(1985/1986). Hence, the annual value was 3 to 10 times higher in 1984/1985 than in the other years (Wefer and Fischer, 1991). The annual flux of organic carbon varied between 7.7, 0.35 and $1.1 \mathrm{gC}$ $\mathrm{m}^{-2} \mathrm{yr}^{-1}$ in the respective years, and hence carbon was 7 to 22 times greater than the values in 1983/1984. However, the most striking feature in the Southern Ocean is that particle export is characterised by high seasonality and is restricted to a short period of the year (Platt, 1979; Matsuda et al., 1987; Fischer et al., 1988; Wefer et al. 1988; Wefer and Fischer, 1991; Cripps and Clarke, 1998; Dunbar et al., 1998; Accornero et al., 1999; Collier et al., 2000; Langone et al., 2000; Palanques et al., $2002 \mathrm{a}$; b).

Sedimentation is often confined to two to four months in the austral spring and summer when sea ice starts to melt and over $80 \%$ of the total annual flux occurs (Table 1). In the Ross Sea a time delay of 2 to 12 weeks between the ice retreat and the peak export of particles was observed (Dunbar et al., 1998), whereas in the northern central Weddell Sea it lasted for 10 weeks (Fischer et al., 1988).

During the winter, particle fluxes are extremely low under the ice-covered sea surface (Fischer et al., 1988; Wefer et al., 1990; Cripps and Clarke, 1998; Dunbar et al., 1998; Accornero et al., 1999; Collier et al., 2000; Honjo et al., 2000; Langone et al., 2000). Contrastingly in the layer near the seabed, due to lateral advection and resuspension, total mass fluxes can be higher in winter than in summer (Berkman et al., 1986; Palanques et al., 2002a; b; Baldwin and Smith, 2003).

\section{Daily flux rates}

Short-term studies on flux rates, mainly carried out in austral spring and summer in neritic Antarctic regions, revealed daily flux rates ranging from approximately $10^{2}$ to $10^{3} \mathrm{mgC} \mathrm{m}^{-2}$ (Karl et al., 1991). However, a high temporal and spatial variability in the amount and composition of trapped matter has been recorded throughout the Southern Ocean (Schnack, 1985; Bodungen et al., 1986; Matsuda et al., 1987; Bathmann et al., 1991; Fischer et al., 1991; Karl et al., 1991; Nelson et al., 1996; Dunbar et al., 1998; Smith and Dunbar, 1998; Frignani et al., 1999; Schloss et al., 1999; Serret et al., 2001).

Short-term sediment trap deployments at shallow depths in various coastal sites indicate that loss rates are generally low (Palanques et al., 2002b). With a few exceptions, higher rates were found mainly when euphausiid faeces dominated trap collections
(Schnack, 1985; Bodungen et al., 1987; 1888; Cadée, 1992).

\section{Spatial and temporal variability}

Spatial differences were observed in many areas of the Southern Ocean. Intensive studies on particle flux carried out over several years in the Ross Sea have shown quite variable quantities and compositions among different sites and years (Leventer and Dunbar, 1996; Nelson et al., 1996; Dunbar et al., 1998; Smith and Dunbar, 1998; Asper and Smith, 1999; Collier et al., 2000; Gardner et al., 2000). Carbon flux is highest in the southwestern and southeastern-central Ross Sea (65.4 and $74.8 \mathrm{mgC}$ $\mathrm{m}^{-2}$ day $^{-1}$ respectively) and lowest in the northwestern part $\left(8.2 \mathrm{mgC} \mathrm{m}^{-2} \mathrm{day}^{-1}\right)$. In the southwest, tabular aggregates and faecal pellets accounted for $69 \%$ of the total mass flux at $230 \mathrm{~m}$ depth, but only $11 \%$ at $719 \mathrm{~m}$ depth. The traps also included small ellipsoidal pellets (possibly from copepods), which on average represented $2 \%$ of the total flux. The traps at the northwestern site received the highest fluxes of diatom tests, which were dominated by the pennate diatoms Fragilariopsis curta and F. cylindrus. In the southeastern-central Ross Sea, pellets and aggregates represented a much smaller percentage of the total mass flux (38 and $4 \%$ at 230 and $519 \mathrm{~m}$ depth respectively). Small ellipsoidal faecal pellets accounted for less than 3\%. Algal diversity was very high, with high numbers of the prymnesiophyte Phaeocystis, dinoflagellates and the diatoms Fragilariopsis and Thalassiosira. In the northern Ross Sea large tabular aggregates and pellets represented the smallest percentage of all sites $(<15 \%)$. Large cylindrical pellets, probably from euphausiids, were only observed there. Within the diatom flux, F. curta comprised $>70 \%$ (Jaeger et al., 1996; Leventer and Dunbar, 1996; Nelson et al., 1996; Dunbar et al., 1998).

The Gerlache Strait at the Antarctic Peninsula seems to be an area of higher spring-summer sedimentation than other Antarctic regions. Serret et al. (2001) and Anadón et al. (2002) observed a high carbon export in the high chlorophyll, diatom-dominated Gerlache Strait $\left(390-800 \mathrm{mgC} \mathrm{m}^{-2} \mathrm{~d}^{-1}\right)$ as compared with the low chlorophyll, microflagellatedominated Bransfield Strait and Drake Passage (115-237 mgC m-2 $\left.\mathrm{d}^{-1}\right)$. At low-chlorophyll stations dominated by flagellates, the sediment trap samples consisted mainly of unidentified amorphous material, while at high-chlorophyll stations dominated by 
diatoms the sediment trap samples showed a large amount of diatoms and euphausiid faeces. The number of faecal pellets varied extremely between stations: $0-0.2 \times 10^{6} \mathrm{~m}^{-2} \mathrm{~d}^{-1}$ at low-chlorophyll stations and between 0.2 and $1.3 \times 10^{6} \mathrm{~m}^{-2} \mathrm{~d}^{-1}$ at high-chlorophyll stations (Anandón et al., 2002). However, despite the marked differences in phytoplankton biomass and species composition no differences in the calculated phytoplankton biomass growth and loss rates were observed between regions (Serret et al., 2001; Anadón et al., 2002). Hence, no significant differences in daily loss rates occurred between high- and low-chlorophyll $a$ stations, which support the idea of Rivkin et al. (1996) that sedimentation processes are independent of the main trophic mode.

In the same region, spatial and temporal differences were observed by Karl et al. (1991) from December 1986 to March 1987, when a nearly constant downward flux of particulate matter was found in shallow waters off Livingston and Low islands (Bransfield Strait) and in deep waters of the Drake Passage, with POC and PON fluxes varying by a factor of $<3$. In contrast, two stations, one in a deep basin in the central Bransfield Strait and the other in coastal waters of the Gerlache Strait, both with a significant phytoplankton bloom followed by the coupled cessation of particle production and flux, showed a marked seasonal variation of 1-2 orders of magnitude. The highest flux was recorded in January and very low values in March. Resting spores of Chaetoceros dominated the sediment trap samples at all stations except in the Drake Passage, where Nitzschia kerguelensis, characteristic of the Antarctic circumpolar current, was most abundant (Leventer, 1991). The high-phytoplankton-bloom stations contained substantial amounts of faecal pellets, mostly from krill, indicating grazing activities (Karl et al., 1991). However, seasonally integrated total mass fluxes were essentially identical for the entire four months of observations at all five stations, and hence the overall flux over the region seems to be similar despite the substantial differences in primary production in the euphotic layer. One consequence of these differences in the seasonal particle flux patterns is that the benthic habitats would receive a more well-defined and more concentrated pulse of organic matter, which may influence the timing of reproduction and growth of benthic organisms.

Relatively high daily sedimentation rates were recorded on the eastern shelf of the Weddell Sea in January-February 1985 (18 and $135 \mathrm{mgC} \mathrm{m}^{-2} \mathrm{~d}^{-1}$, Bodungen et al., 1988) and in the same months in
1988 (3 and $112 \mathrm{mgC} \mathrm{m}{ }^{-2} \mathrm{~d}^{-1}$, Bathmann et al., 1991). In 1985, the sediment trap samples were dominated by faecal material of different origin, and the most abundant pellets were round, ellipsoidal or triangular (Nöthig and Bodungen, 1989). Two size classes of faecal pellets were encountered. The smallest $(<150 \mu \mathrm{m})$ ranged from 9 to $8,600 \times 10^{3}$ $\mathrm{m}^{-2} \mathrm{~d}^{-1}$, constituting between 50 and $99 \%$ of the total faeces settled in the traps, and were supposedly produced by protozoans (ciliates, radiolarians, heterotrophic dinoflagellates and foraminifers). The largest $(>150 \mu \mathrm{m})\left(2\right.$ to $\left.252 \times 10^{3} \mathrm{~m}^{-2} \mathrm{~d}^{-1}\right)$ were nearly round and represented a mean of $64 \%$ by volume of the vertical pellet flux. These pellets were of unknown origin but were probably produced by metazoans. All faecal pellets were filled with intact but empty diatom frustules. Copepod faecal pellets occurred rarely but steadily in the traps, whereas krill faeces were only occasional. However, daily vertical fluxes were highest where krill faeces were present in the traps (Bodungen et al., 1988). Bathmann et al. (1991) observed three distinct sedimentation pulses in 1988. Empty diatoms and small faecal pellets were most numerous during the first pulse, but krill faeces packed with ice-associated diatoms contributed about $64 \%$ of the sedimented carbon. This indicates heavy grazing of krill in the vicinity of sea ice in mid-January. The second pulse in early February consisted again of round pellets together with minipellets, small planktonic aggregates containing many empty diatom frustules. This change in composition is assumed to be induced by Warm Deep Water sweeping onto the shelf resulting in unfavourable growing conditions for diatoms (Bathmann et al., 1991). Large full cells of Corethron criophilum were the dominants of the third pulse. C. criophilum also dominated the greenish-grey fluff observed during box core studies at $600 \mathrm{~m}$ depth in a trough on the eastern shelf of the Weddell Sea in February 1996, and gave evidence of massive sedimentation events. However, the fluff consisted almost exclusively of frustules and only a few cells were still intact (Barthel, 1997).

\section{Vertical variability}

In shallow areas and mid-water depths most of the material collected in the traps during the spring and summer is of biogenic origin (Asper and Smith., 1999; Palanques et al., 2002b). However, in deeper traps the lithogenic component can be extremely high due to lateral advection and resuspension 
Relative abundance (\%) of faecal pellets types in sediment traps in the eastern Brasfield Strait

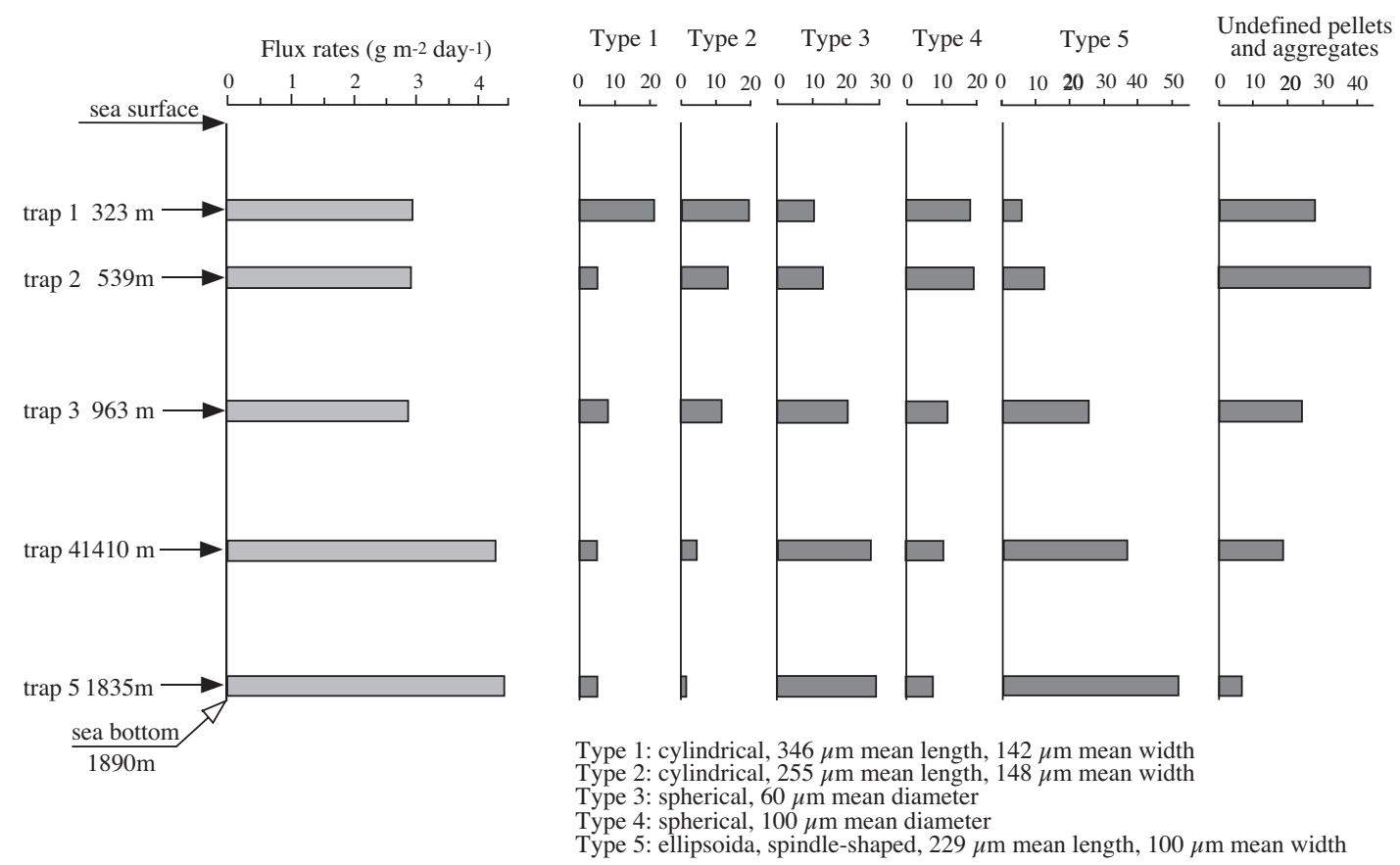

FIG. 2. - Flux rates (a) and relative abundance of different faecal pellets (b) in sediment traps in five different depths in November$\neq$ December 1983 in the eastern Bransfield Strait (after Gersonde and Wefer, 1987).

(Platt, 1979; Domack and Mammome, 1993; Collier et al., 2000; Langone et al., 2000; Isla et al., 2001; Palanques et al., 2002a; b; Baldwin and Smith, 2003). The total mass flux in Johnson`s Dock, a shallow bay at Livingston Island with a water depth of $24 \mathrm{~m}$, varied between 23,235 and $89,073 \mathrm{mg} \mathrm{m}^{-2}$ $\mathrm{d}^{-1}$ in a trap installed $4.5 \mathrm{~m}$ above bottom in summer 1997/1998, when lithogenic components accounted for more than $95 \%$ (Isla et al., 2001). In Port Foster at Deception Island (water depth: $160 \mathrm{~m}$ ), the flux increased in mid-winter, and was positively correlated with local wind speed. Lithogenic material was a major component found in the samples, showing the importance of wind-induced resuspension events on particle fluxes (Baldwin and Smith, 2003). The sedimentation in deeper waters seems to be more linked to the hydrodynamics of the area than to the production in surface waters (Frignani et al., 2000).

In the Bransfield Strait south of Livingston Island in 1995-1996, a deep sediment trap installed

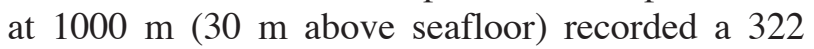
times higher annual total mass flux than that at 500 $\mathrm{m}$ depth during the same sampling period (1326 and $4.11 \mathrm{~g} \mathrm{~m}^{-2} \mathrm{yr}^{-1}$ respectively). The near bottom flux was very high throughout the year (between 1178 and $5321 \mathrm{mg} \mathrm{m}^{-2} \mathrm{~d}^{-1}$ ), without showing a seasonal signal as the shallower trap above it did. Mid-depth fluxes were largely biological and controlled mainly by settling of diatom frustules in spring or faecal material in summer, whereas near-bottom fluxes were mainly controlled by resuspension and lateral transport of material. It is important to mention that the deep trap collected several truly pelagic polychaetes such as Tomopteris sp. and Pelagobia lonvirrata, benthic diatoms (Amphora, Cocconeis, Grammatophora) and also littoral diatom species such as Actinocylus actinochilus, Navicula directa, Thalasiosira antarctica, and Fragilariopsis kerguelensis, indicating resuspension and lateral basinward transport (Palanques et al., 2002a, b).

In the Bransfield Strait south of King George Island in 1983-1984 the total annual flux at 494 and $1588 \mathrm{~m}$ differed only slightly between the two depths (120 and $107.7 \mathrm{~g} \mathrm{~m}^{-2} \mathrm{yr}^{-1}$, and a distinct seasonal variability was evident in both depth strata (Wefer et al., 1988). In short-term sediment trap deployments in December 1983, Gersonde and Wefer (1987) recorded vertical differences in the total flux but also in the composition of faecal pellets (Fig. 2). The total mass flux ranged between 2.9 $\mathrm{g} \mathrm{m}^{-2} \mathrm{~d}^{-1}$ at $323 \mathrm{~m}$ and $4.4 \mathrm{~g} \mathrm{~m}^{-2} \mathrm{~d}^{-1}$ at $1835 \mathrm{~m}$. The higher flux at depth was caused by a strong admixture of resuspended lithogenic material. The estimated pellet flux was $4 \times 10^{5}$ pellets $\mathrm{m}^{-2} \mathrm{~d}^{-1}$ in the upper trap at $323 \mathrm{~m}$, and $6 \times 10^{5}$ pellets $\mathrm{m}^{-2} \mathrm{~d}^{-1}$ in the two lower traps at 1410 and $1835 \mathrm{~m}$. Cylindrical pellets decreased with depth, while the total number of faecal pellets increased with depth (Fig. 2). 
Pack ice
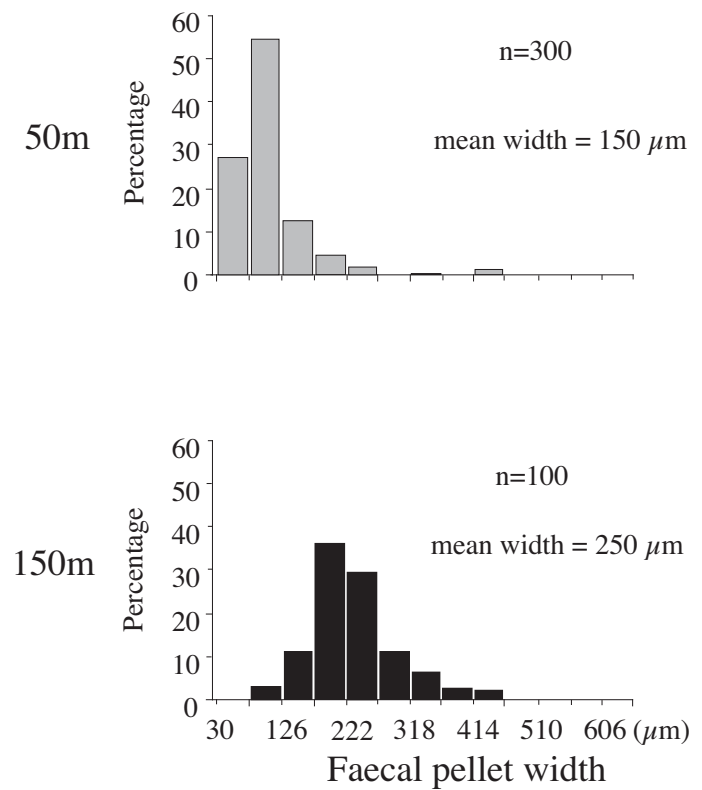

Open water

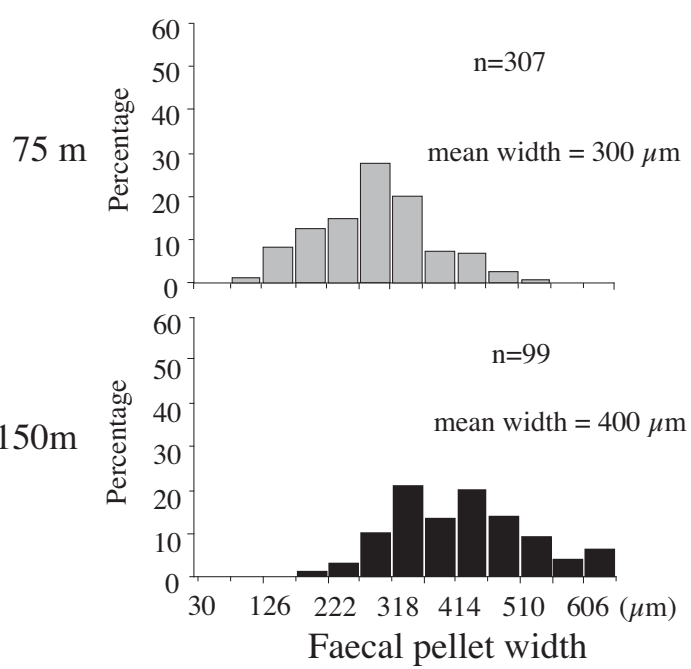

FIG. 3. - Size of krill faecal strings in shallow and deep sediment traps in December 1988 under ice cover (a) and in the melting ice zone (b) (after Cadée et al., 1992).

Diatom frustules in the different faeces were finely shredded into small particles of 1 to $10 \mu \mathrm{m}$. Disintegration seems to be most pronounced between 300 and $1000 \mathrm{~m}$ water depth. Thus, mid-water bacterial breakdown of faecal material may be largely enhanced (Gersonde and Wefer, 1987). In situ repackaging by zooplankton feeding in deeper water, as described by Urrère and Knauer (1981), may lead to a modification of sinking faeces, originally occurring in the upper part of the water column. Evidence of this process in the Bransfield Strait is the increased flux of densely packed, ellipsoidal faecal pellets collected in the deeper traps. The apparent decrease with depth of krill faeces within the carbon flux could be explained by the combined effect of these processes.

Differences in pellet numbers and the length of krill strings in two depth layers were found in the Weddell-Scotia Confluence west of the South Orkney Islands in November-December 1988 (Cadée et al., 1992). The krill strings were larger in the deeper trap at $150 \mathrm{~m}$ than in the shallower one (Fig. 3), indicating that the smallest strings do not leave the upper mixed layer. Besides size, zooplankton diet and pellet shape also seem to influence the vertical distribution and settling velocity of faeces. The highest settling velocities were observed when krill mainly fed on diatoms, whereas after feeding on flagellates the settling velocity decreased (Cadée et al., 1992). Krill strings occurred in higher numbers in shallow traps (116-220 strings $\mathrm{m}^{-2} \mathrm{~d}^{-1}$ at $50-75 \mathrm{~m}$ depth) than in deeper ones (45 to 205 strings $\mathrm{m}^{-2} \mathrm{~d}^{-1}$ at $150 \mathrm{~m}$ depth); contrastingly, small oval pellets of unknown origin found in trap material occurred in greater numbers in deeper layers (4-90 and 110-270 pellets $\mathrm{m}^{-2} \mathrm{~d}^{-1}$ respectively). This is probably due to higher compaction and lower resistance to sinking of the oval pellets (Cadée et al., 1992).

\section{Particle flux from sea ice}

The number of organisms living in the sea ice may exceed that in the water column, and ice algae blooms increase the biomass in the sea ice considerably before primary production in the open water starts (Lizotte, 2003; Schnack-Schiel, 2003 as reviews). However, the role of sea ice within the pelagic-benthic coupling has rarely been studied (Fukuchi and Sasaki, 1981; Matsuda et al., 1987; Dunbar et al., 1989; Pusceddu et al., 1999; Thomas et al., 2001). Ice algae tend to form aggregates, whose sinking rates are three orders of magnitude higher than those of dispersed ice algae, and hence they contribute greatly to the vertical flux (Riebesell et al., 1991). In the eastern Weddell Sea, sedimentation of ice algae on the continental shelf $(<500 \mathrm{~m}$ depth) directly from the sea ice represent an important organic matter flux to the benthic realm during the austral spring and summer (Isla et al., unpubl.). This phytoplankton pulse occurs before the herbivo- 
rous zooplankton massively graze on the algal community and represents a rapid, rich organic matter transfer to the sea floor.

Later in season, in February 1998, the settled material collected under a well-developed platelet ice layer in Drescher Inlet in the Riiser Larsen ice shelf, eastern Weddell Sea, was predominantly composed of faecal pellets (Thomas et al., 2001). The sediment traps were deployed at $10 \mathrm{~m}$ (just under the platelet layer), $115 \mathrm{~m}$ (above the thermocline), $230 \mathrm{~m}$ (below the thermocline) and $360 \mathrm{~m}$ (close to the sea floor). The highest fluxes of faecal pellets but also of chlorophyll $a$ and phaeopigments were collected at $230 \mathrm{~m}$, just below the thermocline. POC occurred in higher amounts in the traps at both sides of the thermocline (Fig. 4). The faecal pellets were of undefined shape or very compact spherical pellets. More than $50 \%$ of the pellets in all traps were smaller than $97 \mu \mathrm{m}$ in diameter and were probably produced by protists. The bottom trap had the greatest proportion of large pellets, and up to $20 \%$ of the pellets were more than $244 \mu \mathrm{m}$ in diameter. They were probably produced by amphipods, which were collected in the traps at all depths together with calanoid and cyclopoid copepods. Regardless of the size of the faecal pellets, the contents were almost exclusively frustules of the ice-diatom genus Fragilariopsis, and mostly $F$. cylindrus and $F$. curta. Most striking was that the diatoms were largely intact and often in chains several cells long (Thomas et al., 2001).

\section{VERTICAL MIGRATION OF ZOOPLANKTON}

Diel vertical migration is known for e.g. the Antarctic copepod Metridia gerlachei (e.g. Rudyakov and Voronina, 1974; Lopez and Huntley, 1995; Hernández-Léon et al., 2001; King and LaCasella,
2003) and the euphausiids Euphausia superba and $E$. crystallorophias (e.g. Siegel and Kalinowsli, 1994; Hernández-Léon et al., 2001; Kaufmann et al., 2003). Krill aggregations were found close to the seafloor $(<2 \mathrm{~m})$ at 400-500 $\mathrm{m}$ depth in the eastern Weddell Sea shelf in January 1988 (Gutt and Siegel, 1994). This epibenthic behaviour was also observed in shallow waters (40 m depth) of Lützow-Holm Bay where krill were feeding on detrital matter on the seabed, and was suggested to be an overwintering strategy of $E$. superba (Kawaguchi et al., 1986). Overwintering in deep water layers is also known for other Antarctic zooplankton species (Smith and Schnack-Schiel, 1990). Seasonal downward migrating species may arrive close to the bottom to hibernate and provide a rich, seasonally predictable food source for benthic invertebrates. For example, the copepod Calanoides acutus, which undergoes such ontogenetic seasonal vertical migrations, was found in higher numbers in the guts of the echinoderm Astrotoma agassizii later in summer on the eastern shelf of the Weddell Sea (Fig. 5, Dahm, 1994), and salp Salpa thompsoni of 1 to $5 \mathrm{~cm}$ in length were found in the stomachs of the anthozoan Anthomastus bathyproctus in summer off the Antarctic Peninsula (Orejas et al., 2001).

\section{PLANKTONIC LARVAE (MEROPLANKTON) OF BENTHIC ORGANISMS}

Arntz et al. (1994) and Arntz and Gili (2001) summarised 20 meroplanktonic larvae types, eight as planktotrophic, four as lecitrophic and eight as not exactly known. Spawning of benthic organisms producing planktotrophic larvae, and hence feeding larvae, should be triggered by a seasonal control so the larvae appear at the same time as the phytoplankton bloom occurs, while species with

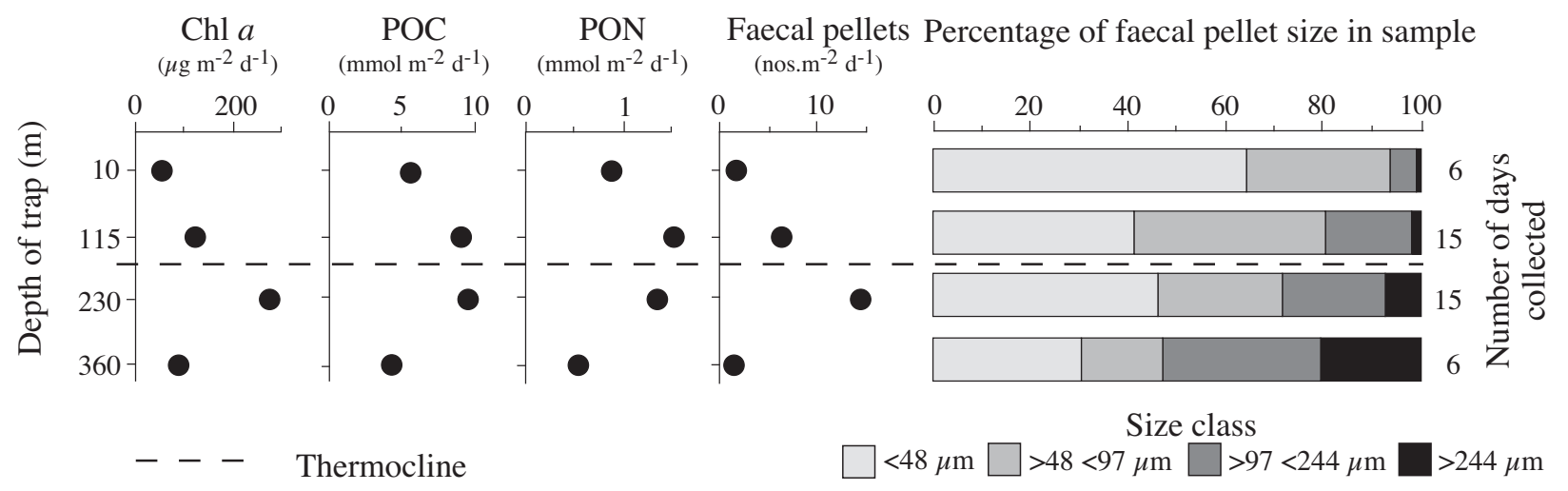

FIG. 4. - Chlorophyll $a$, particulate organic carbon (POC) and nitrogen (PON), and size distribution of faecal pellets in sediment traps in different depth layers in February 1998 under a platelet-ice layer/fast ice at Drescher Inlet in the eastern Weddell Sea (after Thomas et al, 2001). 


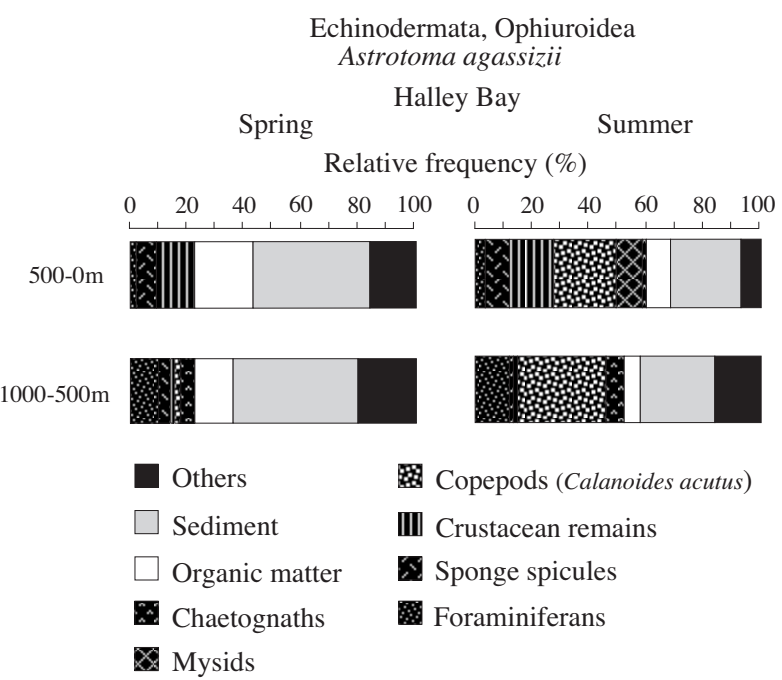

FIG. 5. - Relative abundance of food in the guts of the echinoderm Astrotoma agassizii in summer (after Dahm, 1994).

lecithotrophic larvae are weakly coupled to phytoplankton production. In shallow Antarctic waters, a relatively large number of planktotrophs occurs among the benthic species. Thus, it seems to be of advantage to have a dispersive larval phase in unstable environments with high disturbance conditions (Poulin et al., 2002).

In McMurdo Sound, Pearse et al. (1991) yielded 12 meroplanktonic larvae within shallow-water asteroid, only two of which were brooders. However, only three of the larvae were feeding, whereas the others had pelagic lecithotrophic larvae. In the Bellingshausen Sea, 12 larvae types from seven phyla were described by Shreeve and Peck (1995). By far the highest number of different pelagic larval forms (131) was detected by Stanwell-Smith et al. (1999) in a two year study at Signy Island, Scotia Sea. However, the overall abundance of the larvae was very low compared to temperate and tropical areas. The number of larval types is low taking into account the great species richness in the Antarctic benthos (Clarke and Johnston, 2003). The meroplanktonic larvae occurred throughout the year but with different seasonal patterns (Fig. 6). Echinoderm and gastropod larvae occurred in the highest numbers in winter, mollusc and annelid larvae in summer. However, up to now the feeding mode is not known for most larvae. Hain and Arnaud (1992) studied the reproductive modes of 66 molluscan species in the Weddell Sea and observed planktotrophic or lecithotrophic larval stages in 27 bivalves. However, only two species of meroplanktonic gastropod larvae ("Echinospira" and "Limacosphaera" of the families Capulidae and Lamellari- idae respectively) are relatively often found in plankton samples from the epipelagial (BoysenEnnen, 1987; Piatkowski, 1987; Schiel, unpubl.). In contrast, the bivalve larvae seem to live demersally. Pelagic larval stages are also known from benthic shrimps (Boysen-Ennen, 1987; Piatkowski, 1987) and barnacles (Foster, 1989). Up to now only little is known about the duration of the meroplanktonic lavae in the pelagial. Decapod larvae seem to spend only an extremely short period in the water column, whereas Limacosphaera larvae can live for more than a year in the pelagial (Arntz and Gili, 2001).

A relatively well-studied species is the common bivalve Adamussium colbecki. The flux in summer induces relevant changes in body weight and gonadsomatic index of A. colbecki (Albertelli et al., 1998). Hence, this species is able to take advantage of the short but intense food supply, storing energy for spawning. This species produces unprotected planktotrophic larvae, which feed in the water column (Berkman et al., 1991).

\section{PELAGIC-BENTHIC COUPLING IN THE MAGELLAN REGION}

Our current knowledge of pelagic-benthic coupling in the Magellan region is extremely limited. Up to now there are only a few references to parti-

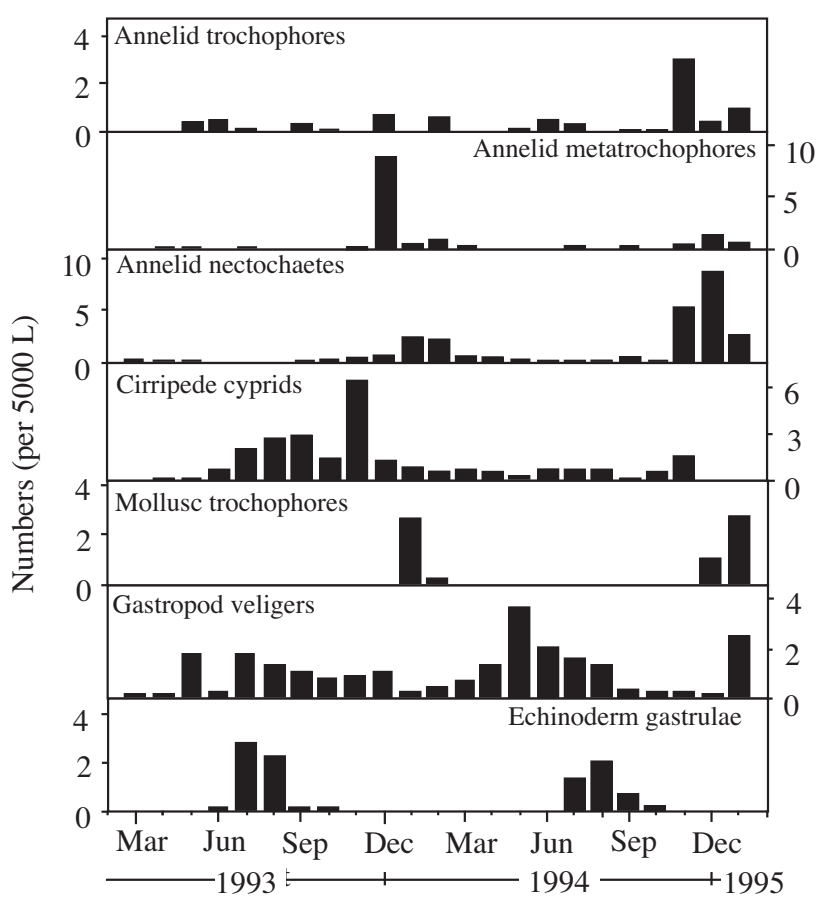

FIG. 6. - Abundance of selected larval groups at Signy Island in November 1992 to February 1995 (after Stanwell-Smith et al., 1999). 
cle flux in this region (see e.g. Antezana, 1999; Cattaneo-Vietti et al., 1999). The hydrographic regime is very complex and shows great spatial variability in geomorphology, currents, temperature, salinity, phytoplankton biomass and production as well as in composition and origin of particulate organic matter (Hamamé and Antezana, 1999; Cattaneo-Vietti et al., 1999). According to Antezana (1999), pelagicbenthic coupling is particularly important in the Magellan region, and a strong link between phytoplankton, vertical migrations of zooplankton and the benthos is evident. In spring the plankton is dominated by large diatoms, suggesting a short food chain, where most of the phytoplankon bloom may sink to the seafloor (Antezana, 1999). Greenish mats, which frequently cover the seafloor in spring indicate heavy sedimentation of phytodetritus largely unutilised by the benthos (Gutt and Schiekan, 1996). In summer, chlorophyll concentrations are much lower than in spring. Pico- and nanoplankton predominate and a more complex food web develops (Antezana, 1999). The few studies on benthic communities in this region show that the communities are poor and less structured than those in many parts of the Antarctic. Deposit feeders, scavengers and omnivores dominate (Cattaneo-Vietti et al., 1999), whereas epibenthic suspension feeders are dominant in the high Antarctic (Brey and Gerdes, 1997; 1999). Cattaneo-Vietti et al. (1999) suggested that one reason may be the high inorganic material from glaciers in the Straits of Magellan, which can impede and damage the filtering structures of the suspension feeders. Despite previous efforts within the first IBMANT symposium in 1997, the study of benthic community differences between the highand sub-Antarctic still offers a great opportunity to increase our knowledge in polar and particularly Antarctic ecology.

The euphausiid Euphausia vallentini is the most abundant krill in the Magellan region, where it is often found in dense swarms, performing intense vertical migrations between the upper $50 \mathrm{~m}$ and the stratum overlying the seabed (Guglielmo et al., 1997). In comparison with the Antarctic krill, Euphausis superba, it is likely that the sinking of the faecal strings of $E$. vallentini contributes substantially to the vertical flux in this area. This species can also fuel carnivorous benthos organisms due to its vertical migrations.

The amount of meroplanktonic larvae is much higher in the Magellan region than in the Antarctic. In the upper $50 \mathrm{~m}$ of the water column, meroplank-

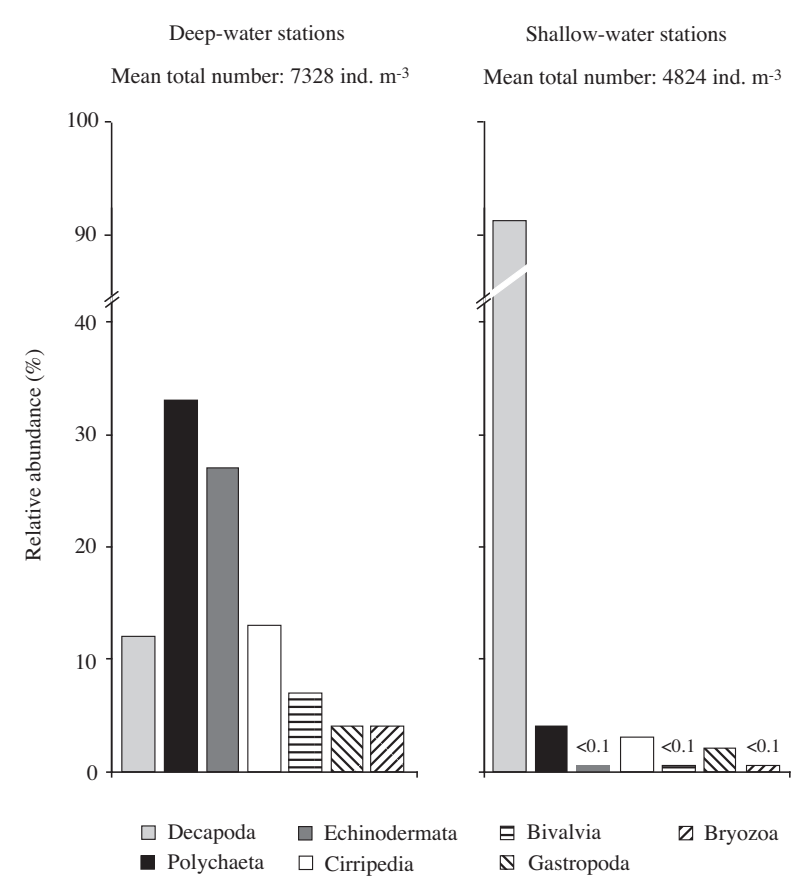

FIG. 7. - Relative abundance of meroplankton in the Magellan region in November 1994 (after Thatje et al., 2003).

ton (mainly pluteus and zoea larvae) contributed numerically between 6 and $42 \%$ of the total zooplankton (Hamamé and Antezana, 1999). Thatje et al. (2003) observed differences between the deepwater stations south of the Straits of Magellan and shallow-water stations in the Beagle Channel. At the deep stations, the composition of the meroplankton was more heterogeneous and larvae of polychaetes and echinoderms were most abundant. In contrast, decapod larvae formed the bulk of the meroplankton at the shallow stations (Fig. 7). These high abundances of meroplanktonic larvae occurred in spring, and hence coincided with spring bloom conditions, which implies a strong pelagic-benthic coupling (Antezana, 1999).

\section{CONCLUDING REMARKS}

Pelagic-benthic coupling in the Southern Ocean is highly seasonal and most evident in the transport of energy within zooplankton faecal pellets. These particles and diatom aggregates transport most of the organic matter, which fuels the underlying benthos. However, there apparently exists much activity throughout the autumn-winter months, when benthic larval releases and resuspension may feed zooplankton migrating close to the seabed. Thus, zooplankton migrations strengthen the coupling 
between the two environments, emphasising the important role of zooplankton in the Southern Ocean pelagic-benthic coupling.

Sedimentation processes have received considerable attention in the Antarctic since the first IBMANT congress in 1997, and many investigations have been carried out in the Ross and Weddell Seas and west of the Antarctic Peninsula (Dunbar et al., 1998; Pusceddu et al., 1999; Isla et al., 2001; Serret et al, 2001; Smith et al., 2001; Thomas et al., 2001; Anadón et al., 2002; Palanques et al., 2002a; b; Badwin and Smith, 2003). However, the role of zooplankton within the processes of pelagic-benthic coupling is not yet fully understood. The identification of faecal pellet material is still problematic, and should be improved to evaluate the contribution of dominant micro-, meso- and macrozooplankton taxa to the coupling between both environments.

More detailed sedimentation experiments should be conducted underneath different sea ice types (e.g. pack, fast, platelet) as well as underneath permanent ice cover. Very little is known about the quantitative importance of the microbial-microzooplankton food web in the Southern Ocean and the significance of these organisms for particle fluxes, pelagic-benthic coupling and marine biogeochemical cycles (already pointed out 20 years ago by Clarke, 1985).

Increasingly we are discovering that there are more planktonic larvae in Southern Ocean waters. This trend is likely to continue with the development of proper methods and better sampling gear such as pumps and nets handled by divers. Annual seasonal studies will also help to elucidate these issues. General studies on all aspects of pelagic-benthic coupling during different seasons are still required for the Magellan region.

\section{ACKNOWLEDGEMENTS}

The first author would like to thank the organisers of the IBMANT congress for the invitation to present this keynote.

\section{REFERENCES}

Accornero, A. and M.M. Gowing. - 2003. Annual sedimentation pattern of zooplankton fecal pellets in the southern Ross Sea: what food webs and processes does the record imply? Antarct. Res. Ser., 78: 261-278.

Accornero, A., A. Berganasco, A. Monaco and S. Tucci. - 1999. Particle fluxes at the edge of the Ross Ice Shelf: the role of physical forcing. In: G. Spezie and G. M. R. Guiseppe (eds.),
Oceanography of the Ross Sea, Antarctica, pp. 177-195. Springer, Berlin.

Albertelli, G., R. Cattaneo-Vietti, M. Chiantore, A. Pusceddu and M. Fabiona. - 1998. Food availability to an Adamussium bed during the austral summer 1993/1994 (Terra Nova Bay, Ross Sea). J. Mar. Syst., 17: 425-434.

Anadón, R., F. Alvarez-Marqués, E. Fernández, M. Varela, M. Zapata, J.M. Gasol and D. Vaqué., - 2002. Vertical biogenic particle flux during austral summer in the Antarctic Peninsula area. Deep-Sea Res. II, 49: 883-901.

Angel, M.V. - 1984. Detrital organic fluxes through pelagic ecosystems. In: M.J.R. Fasham (ed.), Flows of energy and materials in marine ecosystems, pp. 475-516. Plenum Press.

Angel, M.V. - 1989. Does mesopelagic biology affect the vertical flux? In: W.H. Berger, V.S. Smetacek and G. Wefer (eds.), Productivity of the ocean: present and past, pp. 155-173. Wiley, Chichester.

Antezana, T. - 1999. Plankton of Southern Chilean fjords: trends and linkages. Sci. Mar. 63(Suppl. 1): 69-80.

Arntz, W.E. and J.M. Gili. - 2001. A case for tolerance in marine ecology: let us not put out the baby with the bathwater. Sci. Mar., 65: 283-299.

Arntz, W.E., T. Brey and V.A. Gallardo. - 1994. Antarctic zoobenthos. Oceanogr. mar. Biol. ann. Rev., 32: 241-304.

Asper, V.L. and W.O. Smith Jr. - 1999. Particle fluxes during austral spring and summer in the southern Ross Sea. J. Geophys. Res., 104: 5345-5360.

Baldwin, R.J. and K.L. Smith Jr. - 2003. Temporal dynamics of particulate matter fluxes and sediment community response in Port Foster, Deception Island, Antarctica. Deep-Sea Res. II, 50: 1707-1725.

Baldwin, R.J., R.C. Glatts and K.L. Smith Jr. - 1998. Particulate matter fluxes into the benthic boundary layer at a long timeseries station in the abyssal NE Pacific: composition and fluxes. Deep-Sea Res. II, 45: 643-666.

Barthel, D. - 1997. Presence of fluff in an Antarctic shelf trough, at 600 m depth. Ber. Polarforsch., 249: 16-17.

Bathmann, U., G. Fischer, P.J. Müller and D. Gerdes. - 1991. Shortterm variations in particulate matter sedimentation off Kapp Norvegia, Weddell Sea, Antarctica: relation to water mass advection, ice cover, plankton biomass and feeding activity. Polar Biol., 11: 185-195.

Beaulieu, S.E. - Accumulation and fate of phytodetritus on the sea floor. Oceanogr. Mar. Biol. Ann Rev., 40: 171-232.

Berkman, P.A., D.S. Marks and G.P. Shreve. - 1986. Winter sediment resuspension in McMurdo Sound, Antarctica, and its ecological implications. Polar Biol., 6: 1-3.

Berkman, P.A., T.R. Waller and S.P. Alexander. - 1991. Unprotected larval development in the Antarctic scallop Adamussium colbecki (Mollusca: Bivalvia: Pectinidae). Antarct. Sci., 3: 151157

Billet, D.S.M., R.S. Lampitt, A.L. Rice and R.F.C. Mantoura. 1983. Seasonal sedimentation of phytoplankton to the deep-sea benthos. Nature, 302: 520-522.

Bishop, J.K.B., J.M. Edmond, D.R. Ketten, M.P. Bacon and W.B. Silker. -1977 . The chemistry, biology and vertical flux of particulate matter from the upper $400 \mathrm{~m}$ of the equatorial Atlantic Ocean. Deep-Sea Res., 24: 511-548.

Bishop, J.K.B., R.W. Collier, D.R. Ketten and J.M. Edmond. 1980. The chemistry, biology and vertical flux of particulate matter from the upper $400 \mathrm{~m}$ of the Panama Basin. Deep-Sea Res., 27: 615-640.

Bodungen, B. von. - 1986. Phytoplankton growth and krill grazing during spring in the Bransfield Strait, Antarctica - implications from sediment traps. Polar Biol., 6: 153-160.

Bodungen, B. von, V.S. Smetacek, M.M. Tilzer and B. Zeitzschel. - 1986. Primary production and sedimentation during spring in the Antarctic Peninsula region. Deep-Sea Res., 33: 177-194.

Bodungen, B. von, G. Fischer, E.-M. Nöthig and G. Wefer. - 1987. Sedimentation of krill faeces during spring development of phytoplankton in Bransfield Strait, Antarctica. Mitt. Geol.Paläont. Inst. Univ. Hamburg, SCOPE/UNEP, Sonderband, 62: 243-257.

Bodungen, B. von, E.-M. Nöthig and Q. Sui. - 1988. New production of phytoplankton and sedimentation during summer 1985 in the southeastern Weddell Sea. Comp. Biochem. Physiol, 90B: 475-487.

Boyd, P.W., N.D. Sherry, J.A., J.K.B. BergesBishop, S.E. Calvert, 
M.A. Charette, S.J. Giovannoni, R. Goldblatt, P.J. Harrison and S.B. Moran. - 1999. Transformations of biogenic particulates from the pelagic to the deep ocean realm. Deep-Sea Res., 46:2761-2792.

Boysen-Ennen, E. - 1987. Zur Verbreitung des Meso- und Makrozooplanktons im Oberflächenwasser der Weddell See (Antarktis). Ber. Polarforsch., 35: 1-126.

Brey, T. and D. Gerdes. - 1997. Is Antarctic benthic biomass really higher than elsewhere? Antarct. Sci., 9: 266-267.

Brey, T. and D. Gerdes. - 1999. Benthic community productivity in the Magellan region and in the Weddell Sea. Sci. Mar., 63(Suppl. 1): 145-148.

Bruland, K.W. and M.W. Silver. - 1981. Sinking rates of fecal pellets from gelatinous zooplankton (salps, pteropods, doliolids). Mar. Biol., 63: 295-300.

Buck, K.R., P.A. Bolt and D.L. Garrison. - 1990. Phagotrophy and fecal pellet production by an athecate dinoflagellate in Antarctic sea ice. Mar. Ecol. Prog. Ser., 60: 75-84.

Cadée, G.C. - 1992. Organic carbon in the upper layer and its sedimentation during the ice-retreat period in the Scotia-Weddell Sea, 1989. Polar Biol., 12: 253-259.

Cadée, G.C., H. González and S.B. Schnack-Schiel. - 1992. Krill diet affects faecal string settling. Polar Biol., 12: 75-80.

Cattaneo-Vietti, R., M. Chiantore, C. Misic, P. Povero and M. Fabiano. -1999 . The role of pelagic-benthic coupling in structuring littoral benthic communities at Terra Nova Bay (Ross Sea) and in the Straits of Magellan. Sci. Mar., 63(Suppl. 1): 113-121.

Cho, B.C. and F. Azam. - 1988. Major role of bacteria in biogeochemical fluxes in the ocean's interior. Nature, 332: 441-443.

Clarke, A. - 1985. Energy flow in the Southern Ocean. In: W.R. Siegfried, P.R. Condy and R.M. Laws (eds.), Antarctic nutrient cycles and food webs, pp. 573-591. Springer, Berlin.

Clarke, A. and N.M. Johnston. - 2003. Antarctic marine benthic diversity. Oceanogr. Mar. Biol. Ann. Rev., 41: 47-114.

Collier, R., J. Dymond, S. Honjo, S. Manganini, R. Francois and R. Dunbar. - 2000. The vertical flux of biogenic and lithogenic material in the Ross Sea: moored sediment trap observations 1996-1998. Deep-Sea Res. II, 47: 3491-3520.

Cripps, G.C. and A. Clarke. - 1998. Seasonal variation in the biochemical composition of particulate material collected by sediment traps at Signy Island, Antarctica. Polar Biol., 20: 414-423.

Dagg, M.J., J. Urban.Rich and J.O. Peterson. - 2003. The potential contribution of fecal pellets from large copepods to the flux of biogenic silica and particulate organic carbon in the Antarctic Polar Front region near $170^{\circ} \mathrm{W}$. Deep-Sea Res. II, 50: 675-691.

Dahm, C. - 1996. Ökologie und Populationsdynamik antarktischer Ophiuroiden (Echinodermata). Ber. Polarforsch., 194: 1-289.

Defren-Jason, K., S.B. Schnack-Schiel and C. Richter. - 1999. Mesozooplankton communities in the Magellan region. Sci. Mar., 63(Suppl. 1): 43-50.

Domack, E.W. and K.A. Mammone. - 1993. Modern sedimentation within Andvord Bay, Antarctic Peninsula. Antarct. J. U.S., 28: 97-98.

Duineveld, G.C.A., M.S.S. Lavaleye and E.M. Berghuis. - 2004 Particle flux and food supply to a seamount cold-water coral community (Galicia Bank, NW Spain). Mar. Ecol. Prog. Ser., 277: $13-23$.

Dunbar, R.B. -1984. Sediment trap experiments on the Antarctic continental margin. Antarct. J. U.S., 19: 70-71.

Dunbar, R.B., A.R. Leventer and W.L. Stockton. - 1989. Biogenic sedimentation in McMurdo Sound, Antarctica. Mar. Geol., 85: 155-179.

Dunbar, R.B., A.R. Leventer and D.A. Mucciarone. - 1998.Water column sediment fluxes in the Ross Sea, Antarctica: atmospheric and sea ice forcing. J. Geophys. Res., 103: 30,74130,759 .

Emerson, C.W. and J.C. Roff. - 1987. Implications of fecal pellet size and zooplankton behavior to estimates of pelagic-benthic carbon flux. Mar. Ecol. Prog. Ser., 35: 251-257.

Fabiano, M., M. Chiantore, P. Povero, R. Cattaneo-Vietti, A. Pusceddu, C. Misic and G. Alberelli. - 1997. Short-term variations in particulate matter flux in Terra Nova Bay, Ross Sea. Antarct. Sci., 9: 143-149.

Fischer, G., D. Fütterer, R. Gersonde, S. Honjo, D. Ostermann and G. Wefer. - 1988. Seasonal variability of particle flux in the Weddell Sea and its relation to ice cover. Nature, 335: 426-428.

Foster, B.A. - 1989. Balanomorph barnacle larvae in the plankton at McMurdo Sound, Antarctica. Polar Biol., 10: 175-177.
Fowler, S.W and G.A. Knauer. - 1986. Role of large particles in the transport of elements and organic compounds through the oceanic water column. Prog. Oceanog., 16: 147-194.

Frignani, M., L. Langone, L. Labbrozzi and M. Ravaioli. - 2000. Biogeochemical processes in the Ross Sea (Antarctica). Present knowledge and perspectives. In: F. M. Faranda, L. Guglielmo and A. Ianora (eds.), Ross Sea ecology, pp. 39-50. Springer, Berlin.

Fukuchi, M. and H. Sasaki. - 1981. Phytoplankton and zooplankton standing stocks and downward flux of particulate material around fast ice edge of Lützow-Holm Bay, Antarctica. Mem. Natl Inst. Polar Res., Ser. E 34: 13-36.

Fukuchi, M., H. Hattori, H. Sasaki and T. Hoshiai. - 1988. A phytoplankton bloom and associated processes observed with a long-term moored system in Antarctic waters. Mar. Ecol. Prog. Ser., 45: 279-288.

Gardner, W.D., M.J. Richardson and W.O. Smith Jr. - 2000. Seasonal patterns of water column particulate organic carbon and fluxes in the Ross Sea. Deep-Sea Res. II, 47: 3423-3449.

Gersonde, R. and G. Wefer. - 1987. Sedimentation of biogenic siliceous particles in Antarctic waters from the Atlantic sector. Mar. Micropalaeontology, 11: 311-332.

Gili, J.-M., R. Coma, C. Orejas, P.J. López-González and M. Zabala. - 2001. Are Antarctic suspension-feeding communities different from those elsewhere in the world? Polar Biol., 24: 473-485.

González, H.E. - 1992a. Distribution and abundance of minipellets around the Antarctic Peninsula. Implications for protistan feeding behaviour. Mar. Ecol. Prog. Ser., 90: 223-236.

González, H.E. - 1992b. The distribution and abundance of krill faecal material and oval pellets in the Scotia and Weddell Seas (Antarctica) and their role in particle flux. Polar Biol., 12: 81-91.

González, H.E. and V. Smetacek. - 1994. The possible role of the cyclopoid copepod Oithona in retarding vertical flux of zooplankton faecal material. Mar. Ecol. Prog. Ser., 113: 233-246.

González, H.E., F. Kurbjeweit and U.V. Bathmann. - 1994. Occurrence of cyclopoid copepods and faecal material in the Halley Bay region, Antarctica, during January - February 1991. Polar Biol., 14: 331-342.

Gowing, M.M. and M.W. Silver. - 1985. "Minipellets" a new and abundant size class of marine fecal pellets. J. Mar. Res., 43: 395-418.

Guglielmo, L., T. Antezana, N. Crescenti and A. Granata. - 1997. Euphausiids. In: L. Guglielmo and A. Ianora (eds.), Atlas of marine zooplankton, Strait of Magellan, pp. 87-97. Springer, Berlin.

Gutt, J. and T. Schikan. - 1996. Epibenthic communities analysed by underwater camera. Ber. Polarforsch., 90: 35-42.

Gutt, J. and V. Siegel. - 1994. Benthopelagic aggregations of krill (Euphausia superba) on the deeper shelf of the Weddell Sea (Antarctic). Deep-Sea Res., 41: 169-178.

Gutt, J., A. Starmans and G. Dieckmann. - 1998. Phytodetritus deposited on the Antarctic shelf and upper slope: its relevance for the benthic system. J. Mar. Syst., 17: 435-444.

Hain, S. and P.M. Arnaud. - 1992. Notes on the reproduction of high-Antarctic molluscs from the Weddell Sea. Polar Biol., 12: 303-312.

Hamamé, M. and T. Antezana. - 1999. Chlorophyll and zooplankton in microbasins along the Straits of Magellan-Beagle Channel passage. Sci. Mar., 63(Suppl. 1): 35-42.

Handa, N., T. Nakatsuka, M. Fukuchi, H. Hattori and T. Hoshiai. 1992. Vertical fluxes and ecological significance of organic materials during the phytoplankton bloom during austral summer in Breid Bay, Antarctica. Mar. Biol., 112: 469-478.

Hargrave, B.T. - 1973. Coupling carbon flow through some pelagic and benthic communities. J. Fish. Res. Bd. Can., 30: 13171326.

Hernández-Léon, S., A. Portillo-Hahnefeld, C. Almeida, P. Bécognée and I. Moreno. - 2001. Diel feeding behaviour of krill in the Gerlache Strait, Antarctica. Mar. Ecol. Prog. Ser., 223: $235-242$

Hoffmann, E.E., J.M. Klinck and G.A. Paffenhöfer. - 1981. Concentrations and vertical fluxes of zooplankton fecal pellets on a continental shelf. Mar. Biol., 61: 327-335.

Honjo, S., S.J. Manganini and J.J. Cole. - 1982. Sedimentation of biogenic matter in the deep ocean. Deep-Sea Res., 29: 609-625.

Honjo, S., R. Francois, S. Manginini, J. Dymond and R. Collier. 2000. Particle fluxes to the interior of the Southern Ocean in the 
western Pacific sector along $170^{\circ}$ W. Deep-Sea Res., 47: 35213548.

Huiskin, I., L. Viesca and R. Anadón. - 2004. Particle flux in the subtropical Atlantic near the Azores: influence of mesozooplankton. J. Plankton Res., 26: 403-415.

Isla, E., A. Palanques, V. Alvà, P. Puig and J. Guillén. - 2001. Fluxes and composition of settling particles during summer in an Antarctic shallow bay of Livingston Island, South Shetlands. Polar Biol., 24: 670-676.

Jaeger, J.M., C.A. Nittrouer, D.J. DeMaster, C. Kelchner and R.B. Dunbar. - 1996. Lateral transport of settling particles in the Ross Sea and implications for the fate of biogenic material. $J$. Geophys. Res., 101: 18479-18488.

Joint, I.R. and R.J. Morris. - 1982. The role of bacteria in the turnover of organic matter in the sea. Oceanogr. Mar. Biol. Annu. Rev., 20: 65-118.

Karl, D.M., B.D. Tilbrook and G. Tien. - 1991. Seasonal coupling of organic matter production and particle flux in the western Bransfield Strait, Antarctica. Deep-Sea Res., 38: 1097-1126.

Kaufmann, R.S., E.C. Fisher, W.H. Gill, A.L. King, M. Laubacher and B. Sullivan. -2003 . Temporal patterns in the distribution, biomass and community structure of macrozooplankton and micronekton within Port Foster, Deception Island, Antarctica. Deep-Sea Res. II, 50: 1765-1785.

Kawaguchi, K., O. Matsuda, S. Ishikawa and Y. Naito. - 1986. The overwintering strategy of Antarctic krill (Euphausia superba Dana) under the coastal fast ice off the Ongul Islands in LützowHolm Bay, Antarctica. Mem. Natl. Inst. Polar Res., 44: 67-85.

King, A. and E.L. LaCasella. - 2003. Seasonal variations in abundance, diel vertical migration, and population structure of Metridia gerlachei at Port Foster, Deception Island, Antarctica. Deep-Sea Res. II, 50: 1753-1763.

Kiørboe, T. - 2000. Colonization of marine snow aggregates by invertebrate zooplankton: abundance, scaling, and possible role. Limnol. Oceangr., 45: 479-484.

Kiørboe, T. - 2001. Formation and fate of marine snow: small-scale processes with large-scale implications. Sci. Mar., 65(Suppl. 2): 57-71.

Komar, P.D., A.P. Morse, L.F. Small and S.W. Fowler. - 1981. Analysis of sinking rates of natural copepod and euphausiid fecal pellets. Limnol. Oceanogr., 26: 172-180.

Langone, L., M. Frignani, M. Ravaioli and C. Bianchi. - 2000. Particle fluxes and biogeochemical processes in an area influenced by seasonal retreat of the ice margin (Northwestern Ross Sea, Antartica). J. Mar. Syst., 27: 221-234.

Legendre, L. and J. Le Fèvre. - 1989. Hydrodynamical singularities as control of recycled versus export production in oceans. In: W. H. Berger, V. S. Smetacek and G. Wefer (eds.), Productivity of the ocean: present and past, pp. 49-63. Wiley, Chichester.

Legendre, L. and F. Rassoulzdegan. - 1996. Food-web mediated export of biogenic carbon in oceans: hydrodynamic control. Mar. Ecol. Prog. Ser., 145: 179-193.

Leventer, A. - 1991. Sediment trap diatom assemblages from the northern Antarctic Peninsula region. Deep-Sea Res., 38: 11271143.

Leventer, A. and R.B. Dunbar. - 1987. Diatom flux in McMurdo Sound, Antarctica. Mar. Micropaleontology, 12: 49-64.

Leventer, A. and R.B. Dunbar. - 1996. Factors influencing the distribution of diatoms and other algae in the Ross Sea. J. Geophys. Res., 101: 18489-18500.

Leys, S.P., K. Wilson, C. Holeton, H.M. Reiswig, W.C. Austin and V. Tunnicliffe. - 2004. Patterns of glass sponge (Porifera, Hexactinellida) distribution in coastal waters of British Columbia, Canada. Mar. Ecol. Prog. Ser., 283: 133-149.

Lizotte, M.P. - 2003. The microbiology of sea ice. In: D. N. Thomas and G. S. Dieckmann (eds.), Sea ice. In introduction to its physics, chemistry, biology and geology, pp. 184-210. Blackwell, Oxford.

Longhurst, A.R. - 1976. Vertical migration. In: D. H. Cushing and J. J. Walsh (eds.), The ecology of the seas, pp. 116-137. Blackwell, Oxford.

Lopez, M. D.G. and M.E. Huntley. - 1995. Feeding and diel vertical migration cycles of Metridia gerlachei (Giesbrecht) in coastal waters of the Antarctic Peninsula. Polar Biol., 15: 21-30.

Lorenzen, C.J. and N.A. Welchmeyer. - 1983. The in situ sinking rates of herbivore fecal pellets. J. Plankton Res., 6: 929-933.

Marchant, H.J. and C.V. Nash. - 1986. Electron microscopy of gut contents and faeces of Euphausia superba Dana. In: T. Hoshi- ai, T. Nemoto and Y. Niato (eds.) Proc. $7^{\text {th }}$ Symp. Polar Biol., pp. 167-177. Nat. Inst. Polar Res. Tokyo.

Matsuda, O., S. Ishikawa and K. Kawaguchi. - 1987. Seasonal variation of downward flux of particulate organic matter under the Antarctic fast ice. Proc. NIPR Symp. Polar Biol., 1: 23-34.

Matsuda, O., S. Ishikawa and K. Kawaguchi. - 1990. Seasonal variation of particulate organic matter under the Antarctic fast ice and its importance to benthic life. In: K.R. Kerry and G. Hempel (eds.), Antarctic ecosystems. Ecological change and conservation, pp. 143-148. Springer, Berlin.

Nelson, D.M., D.J. DeMaster, R.B. Dunbar and W.O. Smith, Jr. 1996. Cycling of organic carbon and biogenic silica in the Southern Ocean: estimates of water-column and sediment fluxes on the Ross Sea continental shelf. J. Geophys. Res., 101: 18519-18532.

Nöthig, E.M. and B. von Bodungen. - 1989. Occurrence and vertical flux of faecal pellets of probably protozoan origin in the southeastern Weddell Sea (Antarctica). Mar. Ecol. Prog. Ser., 56: 281-289.

Noji, T.T., K.W. Estep, F. MacIntyre and F. Norrbin. - 1991. Image analysis of faecal material grazed upon by three species of copepods: evidence for coprohexy, coprophagy and coprochaly. J. Mar. Biol. Ass. UK, 71: 465-480.

Orejas, C., J.-M. Gigli, V, Alvà and W.E. Arntz. - 2000. Predatory impact of an epiphytic hydrozoan in an upwelling area in the Bay of Coliumo (Dichato, Chile). J. Sea Res., 44: 209-220.

Orejas, C., J.-M. Gigli, P.J. López-González and W.E. Arntz. 2001. Feeding strategies and diet composition of four Antarctic cnidarian species. Polar Biol., 24: 620-627.

Paffenhöfer, G. A. and S.C. Knowles. - 1979. Ecological implications of fecal pellet size, production and consumption by copepods. J. Mar. Res., 37: 35-49.

Palanques, A., E. Isla, P. Masqué, P. Puig, J.A. Sánchez-Cabeza, J.M. Gili and J. Guillén. - 2002a. Downward particle fluxes and sediment accumulation rates in the western Bransfield Strait: Implications of lateral transport for carbon cycle studies in Antarctic marginal seas. J. Mar. Res., 60: 347-365.

Palanques, A., E. Isla, P. Puig, J.A. Sánchez-Cabeza and P. Masqué. $-2002 \mathrm{~b}$. Annual evolution of downward particle fluxes in the western Bransfield Strait (Antarctica) during the FRUELA project. Deep-Sea Res. II, 49: 903-920.

Pearse, J.S., J.B. McClintock and I. Bosch. - 1991. Reproduction of Antarctic benthic marine invertebrates: tempos, modes, and timing. Amer. Zool., 31: 65-80.

Peinert, R., B. von Bodungen and V.S. Smetacek. - 1989. Food web structure and loss rate. In: W.H. Berger, V.S. Smetacek and G. Wefer (eds.), Productivity of the ocean: present and past, pp. 35-48. Wiley, Chichester.

Piatkowski, U. - 1987. Zoogeographische Untersuchungen und Gemeinschaftsanalysen an antarktischen Makroplankton. Ber. Polarforsch., 34: 1- 150.

Platt, H.M. -1979. Sedimentation and the distribution of organic matter in a sub-Antarctic marine bay. Estuar. Coast. Mar.Sci., 9: 51-63.

Poulin, E., A.T. Palma and J.P. Féral. - 2002. Evolutionary versus ecological success in Antarctic benzhic invertebrates. TREE 17: 218-222.

Povero, P., M. Chiantore, C. Misic, G. Budillon and R. CattaneoVietti. - 2001. Land forcing controls pelagic-benthic coupling in Adelie Cove (Terra Nova Bay, Ross Sea). Polar Biol., 24: 875-882.

Pusceddu, A., R. Cattaneo-Vietti, G. Albertelli and M. Fabiano. 1999. Origin, biochemical composition and vertical flux of particulate organic matter under the pack ice in Terra Nova Bay (Ross Sea, Antarctica) during late summer 1995. Polar Biol., 22: $124-132$.

Riebesell, U., I. Schloss and V. Smetacek. - 1991. Aggregation of algae released from melting sea ice: implications for seeding and sedimentation. Polar Biol., 11: 239-248.

Rivin, R. B., L. Legendre, D. Deibel, J.-E. Tremblay, B. Klein, K. Crocker, S. Roy, N. Silverberg, C. Lovejoy, F. Mesplé, N. Romero, M.R. Anderson, P. Matthews, C. Savenkoff, A. Vézina, J.-C. Therriault, J. Wesson, C. Bérubé and R.G. Ingram. 1996. Vertical flux of biogenic carbon in the ocean: is there food web control. Science, 272: 1163-1166.

Rudyakov, Y.A. and N.M. Voronina. - 1974. Daily vertical migrations of the copepod Metridia gerlachei in the Scotia Sea. Oceanology, 13: 423-426. 
Schloss, I., G.A. Ferreyra, G. Mercuri and J. Kowalke. - 1999. Particle flux in an Antarctic shallow coastal environment: a sediment trap study. Sci. Mar., 63(Suppl. 1): 99-111.

Schnack, S.B. - 1985. A note on the sedimentation of particulate matter in Antarctic waters during summer. Meeresforsch., 30: 306-315.

Schnack-Schiel, S.B. - 2003. The macrobiology of sea ice. In: D.N. Thomas and G.S. Dieckmann (eds.), Sea ice. Introduction to its physics, chemistry, biology and geology, pp. 211-239. Blackwell, Oxford.

Serret, P., E. Fernández, R. Anadón and M. Varela. - 2001. Trophic control of biogenic carbon export in Bransfield and Gerlache Straits, Antarctica. J. Plankton Res., 23: 1345-1360.

Shreeve, R.S. and L.S. Peck. - 1995. Distribution of pelagic larvae of benthic marine invertebrates in the Bellingshausen Sea Polar Biol., 15: 369-374.

Siegel, V. and J. Kalinowski. - 1994. Krill demography and smallscale processes: a review. In: S.Z. El-Sayed (ed.), Southern ocean ecology: the BIOMASS perspective, pp. 145-163. University Press, Cambridge.

Simon, M. and F. Azam. - 1992. Protein content and protein synthesis rates of planktonic marine bacteria. Mar. Ecol. Prog. Ser., 51: 201-213.

Small, L. F. and S.W. Fowler. - 1973. Turnover and vertical transport of zinc by the euphausiid Meganyctiphanes norvegica in the Ligurian Sea. Mar. Biol., 18: 284-290.

Smetacek, V. - 1984. The supply of food to the benthos. In: M.J. Fasham (ed.), Flows of energy and materials in marine ecosystems: theory and practice, pp. 517-548. Plenum Press, New York.

Smith, S.L. and S.B. Schnack-Schiel. - 1990. Polar zooplankton. In: W.O. Smith, Jr. (ed.), Polar oceanography, Part B: chemistry, biology and geology, pp. 527-598. Academic Press, San Diego.

Smith Jr.,W.O. and R.B. Dunbar. - 1998. The relationship between new production and vertical flux on the Ross Sea continental shelf. J. Mar. Syst., 17: 445-457.

Smith Jr., W.O., H.J. Niebauer and V.I. Asper. - 1999. Coupling of surface layer biological processes and vertical flux in the Ross Sea. In: F. M. Faranda, L. Guglielmo and A. Ianora (eds.), Ross Sea ecology, pp. 151-157. Springer, Berlin.
Stanwell-Smith, D., L.S Peck, A. Clarke, A.W.A. Murray and C.D. Todd. - 1999. The distribution, abundance and seasonality of pelagic marine invertebrate larvae in the maritime Antarctic. Phil. Trans. R. Soc. Lond. B, 354: 471-484.

Thatje, S., S.B. Schnack-Schiel and W.E. Arntz. - 2003. Developmental trade-offs in Subantarctic meroplankton communities and the enigma of low decapod diversity in high southern latitudes. Mar. Ecol. Prog. Ser., 260: 195-207.

Thomas, D.N., H. Kennedy, G. Kattner, D. Gerdes, C. Gough and G.S. Diekmann. - 2001. Biogeochemistry of platelet ice: its influence on particle flux under fast ice in the Weddell Sea, Antarctica. Polar Biol., 24: 486-496.

Thorson, G. - 1950. Reproductive and larval ecology of marine bottom invertebrates. Biol. Rev. 25: 1-45.

Turner, J.T. and J.G. Ferrante. - 1979. Zooplankton fecal pellets in aquatic ecosystems. Bioscience, 29: 670-677.

Urrère, M.A. and G.A. Knauer. - 1981. Zooplankton fecal pellet fluxes and vertical transport of particulate organic material in the pelagic environment. J. Plankton Res., 3: 369-387.

Wassmann, P. - 1984. Sedimentation and benthic mineralization of organic detritus in a Norwegian fjord. Mar. Biol., 83: 83-94.

Wefer, G. and G. Fischer. - 1991. Annual primary production and export flux in the Southern Ocean from sediment trap data. Mar. Chem., 35: 597-613.

Wefer, G., E. Suess, W. Balzer, G. Liebezeit, P.J. Müller, C.A Ungerer and W. Zenk. - 1982. Fluxes of biogenic components from sediment trap deployment in circumpolar waters of the Drake Passage. Nature, 299: 145-147.

Wefer, G., G. Fischer, D. Fütterer and R. Gersonde. - 1988. Seasonal particle flux in the Bransfield Strait, Antarctica. Deep-Sea Res., 35: 891-898.

Wefer, G., G. Fischer, D.K. Fütterer, R. Gersonde, S. Honjo and D. Ostermann. - 1990. Particle sedimentation and productivity in Antarctic waters of the Atlantic sector. In: U. Bleil and J. Thiede (eds.), Geological history of the polar oceans: Arctic versus Antarctic, pp. 363-379. Kluwer Academic Publishers, The Netherlands.

Wishner, K.F. - 1980. Aspects of the community ecology of deepsea, benthopelagic plankton with special attention to Gymnopleid copepods. Mar. Biol., 60: 179-187. 
